\title{
The scaffold protein WRAP53ß orchestrates the ubiquitin response critical for DNA double-strand break repair
}

\author{
Sofia Henriksson, ${ }^{1}$ Hanif Rassoolzadeh, ${ }^{1,5}$ Elisabeth Hedström, ${ }^{1,5}$ Christos Coucoravas, ${ }^{1}$ \\ Alexander Julner, ${ }^{1}$ Michael Goldstein, ${ }^{2}$ Gabriela Imreh, ${ }^{3}$ Boris Zhivotovsky, ${ }^{3}$ Michael B. Kastan, ${ }^{2}$ \\ Thomas Helleday, ${ }^{4}$ and Marianne Farnebo ${ }^{1}$ \\ ${ }^{\mathbf{1} D e p a r t m e n t}$ of Oncology-Pathology, Cancer Centrum Karolinska (CCK), Karolinska Institutet, Stockholm 171 76, Sweden; \\ ${ }^{2}$ Department of Pharmacology and Cancer Biology, Duke University School of Medicine, Durham, North Carolina 27710, USA; \\ ${ }^{3}$ Institute for Environmental Medicine, Karolinska Institutet, Stockholm 171 77, Sweden; ${ }^{4}$ Science for Life Laboratory, Division \\ of Translational Medicine and Chemical Biology, Department of Medical Biochemistry and Biophysics, Karolinska Institutet, \\ Stockholm 171 65, Sweden
}

The WD40 domain-containing protein WRAP53 $\beta$ (WD40 encoding RNA antisense to p53; also referred to as WDR79/TCAB1) controls trafficking of splicing factors and the telomerase enzyme to Cajal bodies, and its functional loss has been linked to carcinogenesis, premature aging, and neurodegeneration. Here, we identify WRAP53 $\beta$ as an essential regulator of DNA double-strand break (DSB) repair. WRAP53 $\beta$ rapidly localizes to DSBs in an ATM-, H2AX-, and MDC1-dependent manner. We show that WRAP53 $\beta$ targets the E3 ligase RNF8 to DNA lesions by facilitating the interaction between RNF8 and its upstream partner, MDC1, in response to DNA damage. Simultaneous binding of MDC1 and RNF8 to the highly conserved WD40 scaffold domain of WRAP53 $\beta$ facilitates their interaction and accumulation of RNF8 at DSBs. In this manner, WRAP53 $\beta$ controls proper ubiquitylation at DNA damage sites and the downstream assembly of 53BP1, BRCA1, and RAD51. Furthermore, we reveal that knockdown of WRAP53 $\beta$ impairs DSB repair by both homologous recombination (HR) and nonhomologous end-joining (NHEJ), causes accumulation of spontaneous DNA breaks, and delays recovery from radiation-induced cell cycle arrest. Our findings establish WRAP53 $\beta$ as a novel regulator of DSB repair by providing a scaffold for DNA repair factors.

[Keywords: WRAP53ß; WD40 scaffold; DNA repair; ubiquitin; RNF8 E3 ligase; MDC1]

Supplemental material is available for this article.

Received June 9, 2014; revised version accepted November 4, 2014.

Proper repair of DNA double-strand breaks (DSBs) is critical for the maintenance of genome stability and prevention of disease; e.g., neurodegeneration, premature aging, and cancer (Jackson and Bartek 2009). The DNA damage response (DDR) involves a coordinated series of events that results in the assembly of DNA repair proteins at sites of DNA damage. One of the earliest events in this signaling cascade is the phosphorylation of the histone variant $\mathrm{H} 2 \mathrm{AX}$ at Ser139 (referred to as $\gamma \mathrm{H} 2 \mathrm{AX}$ ) by the ATM/ATR/DNA-PK kinases (Falck et al. 2005). Upon binding to $\gamma \mathrm{H} 2 \mathrm{AX}$, the MDC1 protein mediates signal expansion on the DNA molecule (Stucki et al. 2005) and serves as an anchor for subsequent recruitment of the E3

\footnotetext{
${ }^{5}$ These authors contributed equally to this work. Corresponding author: marianne.farnebo@ki.se

Article is online at http://www.genesdev.org/cgi/doi/10.1101/gad.246546.114 Freely available online through the Genes \& Development Open Access option.
}

ubiquitin ligases RNF8 and RNF168. RNF8 is the first E3 ligase to be recruited to DSBs, which, in conjunction with RNF168, ubiquitylates flanking chromatin (including histones $\mathrm{H} 2 \mathrm{AX}$ and $\mathrm{H} 2 \mathrm{~A}$ ) and promotes efficient assembly of the downstream repair factors 53BP1, BRCA1, and RAD51 at the site of damage (Huen et al. 2007; Mailand et al. 2007; Marteijn et al. 2009; Meerang et al. 2011). The DDR involves accumulation of DNA repair factors at DNA lesions, a process mediated largely by protein interactions.

Scaffold proteins, among which some of the most important are the WD40 domain proteins, tether molecules together and provide backbones for the assembly of signaling complexes. Through their unique WD40 repeats (each repeat consisting of $\sim 40$ amino acid residues, including a tryptophan $\mathrm{W}$ and aspartic acid D C-terminal

(c) 2014 Henriksson et al. This article, published in Genes \& Development, is available under a Creative Commons License (Attribution 4.0 International), as described at http://creativecommons.org/licenses/by/4.0. 
dipeptide), these proteins can interact with several partners simultaneously in a nonexclusive manner, thereby facilitating protein interactions (Stirnimann et al. 2010; $\mathrm{Xu}$ and Min 2011). One such example is PALB2, which provides a scaffold for interactions between BRCA1, BRCA2, and RAD51, thereby anchoring BRCA2 to sites of DNA damage. Defects in PALB2 lead to impaired formation of this complex and defective homologous recombination (HR) repair, highlighting the critical role played by scaffold proteins in the DDR (Xia et al. 2006; Lan et al. 2009; Sy et al. 2009).

WRAP53 $\beta$ (WD40 encoding RNA antisense to p53; also referred to as WDR79/TCAB1), another WD40 domain protein, facilitates interactions between factors involved in splicing and telomere elongation and their localization to nuclear organelles known as Cajal bodies. Accordingly, loss of WRAP53 $\beta$ leads to collapse of these structures and mislocalization of associated factors (Tycowski et al. 2009; Venteicher et al. 2009; Mahmoudi et al. 2010). In addition to the WRAP53 $\beta$ protein, the WRAP53 gene encodes a regulatory RNA (WRAP53 $\alpha$ ) that is produced by usage of an alternative start point for transcription. Although this RNA controls the response of p53 to cellular stress, WRAP53 $\beta$ acts independently of WRAP53 $\alpha$ and does not play a role in the regulation of p53 (Farnebo 2009; Mahmoudi et al. 2009).

Aberrations in WRAP53 $\beta$ have been linked to several genetic disorders. For example, inherited mutations in WRAP53 $\beta$ that affect its WD40 domain cause dyskeratosis congenita, a disorder involving bone marrow failure, premature aging, and cancer predisposition (Zhong et al. 2011). Moreover, SNPs in WRAP53 or altered expression of the protein itself are associated with elevated risk for a variety of sporadic tumors and radioresistant head and neck cancer cells, hematoxicity, and disturbed DNA repair in workers exposed to benzene (Garcia-Closas et al. 2007; Lan et al. 2009; Schildkraut et al. 2009; Mahmoudi et al. 2011; Medrek et al. 2013; Garvin et al. 2014). Furthermore, patients with spinal muscular atrophy, a neurodegenerative disorder that is the leading genetic cause of infant mortality worldwide, exhibit loss of WRAP53 $\beta$ function (Mahmoudi et al. 2010).

Intriguingly, neurodegeneration, aging, and cancer are all processes linked to accumulation of DNA damage. Although this suggests a role for WRAP53 $\beta$ in DNA repair, this role remains unknown. It is noteworthy in this context that WRAP53 $\beta$ has been identified in several proteomic and genome-wide siRNA screens designed to detect factors associated with DDR (Matsuoka et al. 2007; Paulsen et al. 2009; Adamson et al. 2012). These links, together with WRAP53 $\beta$ 's function as a scaffold protein, prompted us to ask whether WRAP53 $\beta$ is involved in the assembly of repair factors at sites of DNA damage and whether loss of this function impairs DNA DSB repair.

\section{Results}

WRAP53 $\beta$ is recruited to sites of DNA damage in an ATM-, H2AX-, and MDC1-dependent manner

To elucidate the involvement of WRAP53 $\beta$ in the DDR, we initially laser-microirradiated U2OS cells and ob- served a rapid relocalization of WRAP53 $\beta$ to DNA lesions. WRAP53 $\beta$ was present at DNA lesions within a few minutes (Fig. 1A), placing this protein high upstream in the DNA damage signaling cascade. This localization of WRAP53 $\beta$ at DNA damage sites was observed in other cell types, including human fibroblasts and H1299 lung cancer cells, and with five different antibodies against WRAP53 $\beta$ (Supplemental Fig. 1A,B). One of the WRAP53 $\beta$ antibodies, mouse monoclonal $\alpha$-WDR79 clone 1F12, revealed formation of WRAP53 $\beta$ foci in response to ionizing radiation (IR) as well as enrichment of WRAP53 $\beta$ in Cajal bodies, confirming its reliability (Supplemental Fig. 1C). Furthermore, the WRAP53 $\beta$ foci clearly overlapped with $\gamma \mathrm{H} 2 \mathrm{AX}$, and the staining was specific, since it could be eliminated by siRNA oligos targeting WRAP $53 \beta$ (Fig. 1B). These WRAP53 $\beta$ foci appeared rapidly following exposure to IR and were dissolved gradually over a period of $24 \mathrm{~h}$, a time course similar to that of $\gamma \mathrm{H} 2 \mathrm{AX}$ foci (Fig. 1C).

We next set out to determine the mechanism for WRAP53 $\beta$ accumulation at DNA lesions and tested for the contribution of three major kinases involved the early steps of the DDR: ATM, ATR, and DNA-PK (Stiff et al. 2004). This revealed that inhibition of ATM activity impaired the recruitment of WRAP53 $\beta$ to DNA damage sites, whereas DNA-PK and ATR were not strictly required for this localization (Fig. 1D,E). Furthermore, accumulation of WRAP53 $\beta$ at DSBs was abrogated by siRNA knockdown of $\mathrm{H} 2 \mathrm{AX}$ and the downstream factor MDC1, both of which serve as anchors for recruitment of downstream factors to DSBs (Fig. 1D,E).

We also investigated the spatiotemporal dynamics of WRAP53 $\beta$ recruitment to the DSB by introduction of DSBs at defined sites in the genome using the I-PpoI homing endonuclease (Goldstein et al. 2013). Chromatin immunoprecipitation (ChIP) revealed that WRAP53 $\beta$ is recruited directly to the break site and, to a lesser extent, to the regions surrounding the DSB (Fig. 1F; Supplemental Fig. 1D). Accumulation of WRAP53 $\beta$ peaked $1 \mathrm{~h}$ after ddIPpoI induction, and WRAP53 $\beta$ disappeared in the DSB surrounding regions $1 \mathrm{~h}$ later, a time course that mimics the kinetics of DNA breakage and repair observed in this model system (Goldstein et al. 2013). Interestingly, WRAP53 $\beta$ remained at the break site beyond the 2-h time point after ddI-PpoI induction, which is a time point at which DNA repair is already completed. Together, these findings indicate that WRAP $53 \beta$ is a novel player in the early ATM-, H2AX-, and MDC1-dependent accumulation of repair factors at sites of DNA damage.

\section{WRAP53 $\beta$ mediates recruitment of DNA repair proteins to DSBs through RNF8-mediated ubiquitylation}

Having established that WRAP53 $\beta$ is involved in the DDR, we wanted to elucidate its mechanism of action in this process. Since WRAP53 $\beta$ is involved in intracellular trafficking, we asked whether WRAP53 $\beta$ could control recruitment of DNA repair proteins to DNA breaks. Interestingly, accumulation of BRCA1, 53BP1, and RAD51 at 


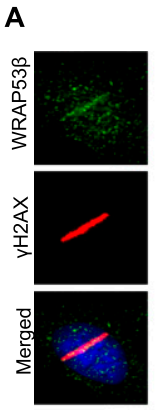

B

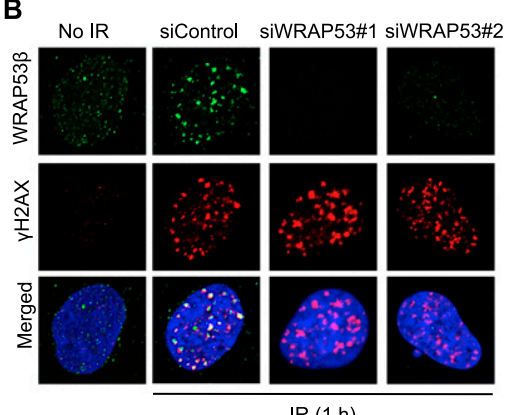

C

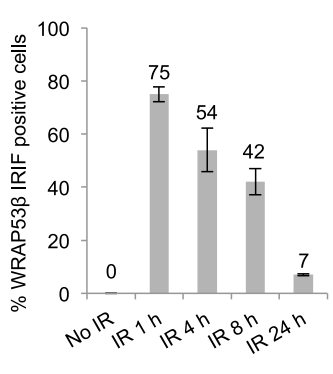

D

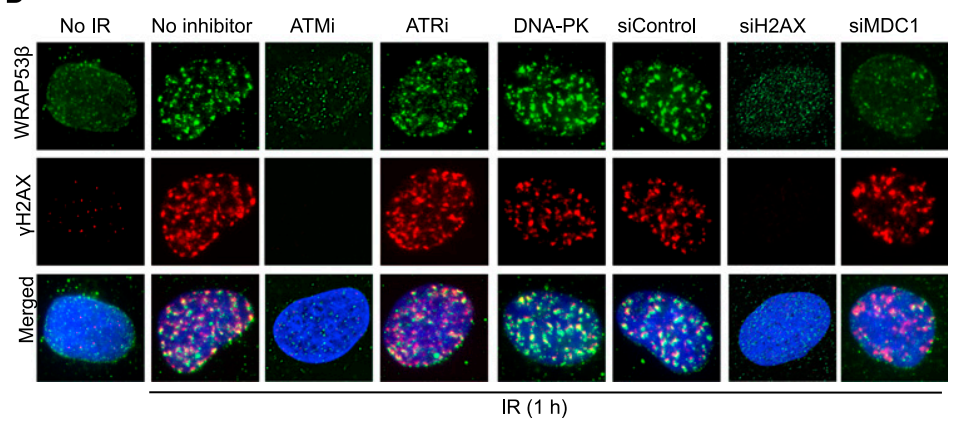

E

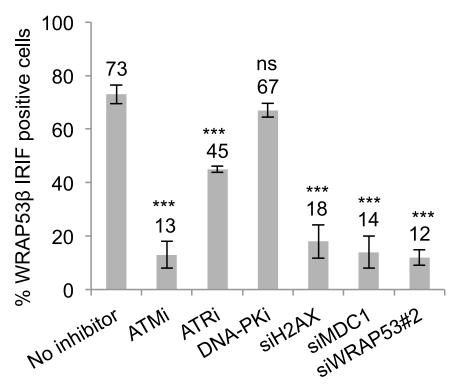

$\mathbf{F}$

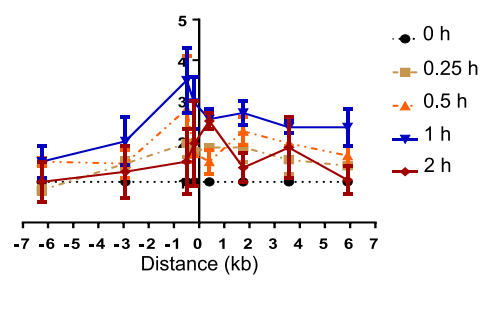

Figure 1. WRAP53 $\beta$ accumulates at sites of DNA damage in an ATM/H2AX/MDC1-dependent manner. (A) U2OS cells were microirradiated, fixed 5 min later, and immunostained for WRAP53 $\beta$ and $\gamma \mathrm{H} 2 \mathrm{AX}$, a marker for DNA DSBs. Nuclei were stained with DAPI in all immunofluorescence experiments. $(B) \mathrm{U} 2 \mathrm{OS}$ cells were treated with siControl or two different WRAP53 $\beta$ targeting oligonucleotides (siWRAP53\#1 and siWRAP53\#2) for $48 \mathrm{~h}$, irradiated (6 Gy, 1-h recovery) or left untreated, fixed after pre-extraction with cytoskeleton (CSK) buffer, and immunostained for WRAP53 $\beta$ and $\gamma \mathrm{H} 2 \mathrm{AX} .(C) \mathrm{U} 2 \mathrm{OS}$ cells were irradiated (6 Gy), fixed, and immunostained for WRAP53 $\beta$ at the indicated time points. Quantification is given as the percentage of the 100 cells counted in each experiment whose nuclei contained WRAP53 $\beta$ IRIF. $(D)$ U2OS cells were treated with the inhibitors or siRNAs, as indicated, for $6 \mathrm{~h}$ or $48 \mathrm{~h}$, respectively; irradiated (6 Gy, 1-h recovery); fixed after pre-extraction with CSK buffer; and immunostained for WRAP53 $\beta$ and $\gamma \mathrm{H} 2 \mathrm{AX}$. $(E)$ Quantification of the results in $D$, as the percentage of the 100 cells counted in each experiment whose nuclei contained WRAP53 $\beta$ IRIF. The error bars depict the SEM; $n=3 ;\left(^{\star \star \star}\right) P<0.001$ as determined by Student's $t$-test. $(F)$ ChIP assay showing the recruitment of WRAP53 $\beta$ to the I-PpoI-induced DSB at chromosome 1 in MCF7 cells stably expressing ddI-PpoI. The time indicated is hours after the addition of 4-OHT. The I-PpoI cleavage site on chromosome 1 is located at distance 0 . Cells were cultivated in medium containing $0.1 \%$ FBS for $24 \mathrm{~h}$ before DSB induction. Data are shown as the mean of two independent experiments. The Y-axis displays the fold change in relative occupancy normalized to the control.
DSBs caused by IR was consistently impaired in cells depleted of WRAP53 $\beta$, whereas the upstream DDR proteins MDC1 and $\gamma \mathrm{H} 2 \mathrm{AX}$ still formed foci (Fig. 2A). Introduction of siRNA-resistant Flag-WRAP53 $\beta$ into cells depleted of endogenous WRAP53 $\beta$ restored formation of DDR foci, which argues against off-targeting effects of the siRNA (Supplemental Fig. 2A-C).

Recruitment of BRCA1, 53BP1, and RAD51 to DSBs requires the ubiquitin ligase RNF8 (Huen et al. 2007; Mailand et al. 2007; Meerang et al. 2011), which we also confirmed here to be the case for RAD51 (Supplemental Fig. 2D). Indeed, depletion of WRAP53 $\beta$ impaired accumulation of both GFP-RNF8 and the E3 ligase RNF168, with which it works in close conjunction at DSBs (Fig. 2B; Doil et al. 2009). A similar reduction in the accumulation of HA-RNF8 at DSBs was observed in WRAP53 $\beta$-depleted cells, whereas HA-MDC1 still formed foci (Supplemental Fig. 2E,F). This reduction of HA-RNF8 did not reflect any decrease in the levels of this protein (Supplemental Fig. $2 \mathrm{G})$. In line with the reduction in the formation of both RNF8 and RNF168 foci, WRAP53 $\beta$ also reduced the total levels of ubiquitin conjugates at DSBs (Fig. 2B,C). The extent of this reduction was comparable with the loss of ubiquitylation caused by depletion of RNF8, RNF168, and MDC1 (Supplemental Fig. 2H). Furthermore, we examined RNF8- and RNF168-specific ubiquitylation of their substrate histone, $\mathrm{H} 2 \mathrm{AX}$, which is important for the recruitment of repair proteins to DSBs (Mailand et al. 2007). Indeed, WRAP53 $\beta$ knockdown reduced H2AX ubiquitylation (Fig. 2D). Together, these data show that WRAP53 $\beta$ is required for localization of RNF8 at DSBs and its subsequent ubiquitylation at these sites, thereby promoting assembly of DNA repair factors at DSBs.

\section{WRAP53 $\beta$ binds the forkhead-associated (FHA) domains of both RNF8 and MDC1}

To obtain additional insight into how WRAP $53 \beta$ recruits RNF8 to DSBs, potential binding of WRAP53 $\beta$ to RNF8 and its upstream partner, MDC1, was explored (Huen et al. 2007; Kolas et al. 2007; Mailand et al. 2007). Indeed, WRAP53 $\beta$ was found to bind both MDC1 and RNF8 (Fig. $3 \mathrm{~A}$; Supplemental Fig. 3A,B) in a specific manner, as demonstrated by knockdown of WRAP53 $\beta$ (Supplemental Fig. 3C). These interactions were enhanced in response to DNA damage, although they were also present in nonirradiated cells (Fig. 3A). In addition, WRAP53 $\beta$ and RNF8 clearly colocalized at sites of DNA damage 
A

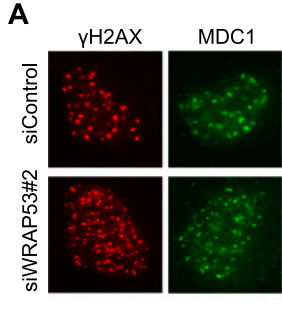

C

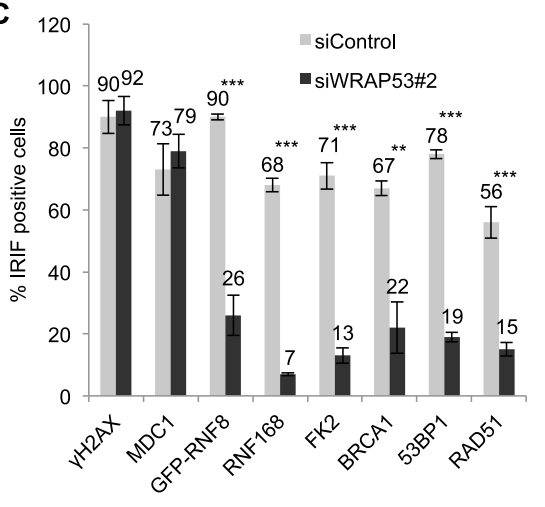

B
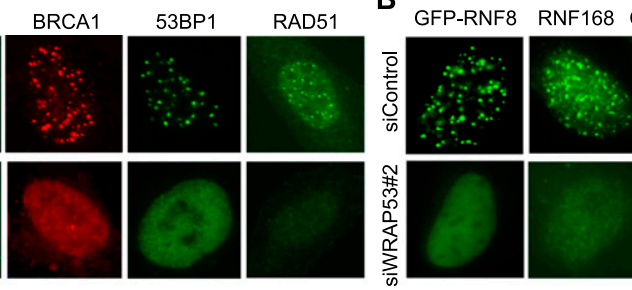

D

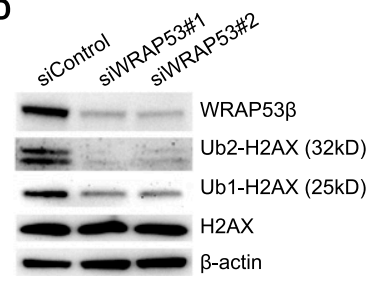

Figure 2. WRAP53 $\beta$ promotes recruitment of repair proteins to DSBs. (A) U2OS cells were transfected with siControl or siWRAP53\#2 oligonucleotides for $24 \mathrm{~h}$, exposed to IR (6 Gy) or left untreated, and, $1 \mathrm{~h}$ later, immunostained for $\gamma \mathrm{H} 2 \mathrm{AX}, \mathrm{MDC} 1, \mathrm{BRCA} 1,53 \mathrm{BP} 1$, and RAD51. $(B)$ U2OS cells treated as in $A$ and then immunostained for RNF168 and conjugated ubiquitin (with the FK2 antibody). In the case of GFPRNF8 staining, following treatment with oligonucleotides for $24 \mathrm{~h}$, the cells were transiently transfected with the GFP-RNF8 plasmid for $8 \mathrm{~h}$, exposed to IR (6 Gy), allowed to recover for $1 \mathrm{~h}$, and then fixed and analyzed. $(C)$ Quantification of the results in $A$ and $B$ as the percentage of 200 cells counted in each experiment whose nuclei contained IRIF. In the case of GFP-RNF8, only successfully transfected cells were counted. $(D)$ U2OS cells were treated with the siRNAs indicated for $24 \mathrm{~h}$, irradiated (6 Gy), allowed to recover for $1 \mathrm{~h}$, and then subjected to Western blotting for WRAP53 $\beta, \mathrm{H} 2 \mathrm{AX}$, and $\beta$-actin. The error bars depict the SEM. $n=3 ;\left(^{\star \star}\right) P<0.01$; $\left(^{\star \star \star}\right) P<0.001$, as determined by Student's $t$-test.

(Supplemental Fig. 3D). To further investigate the binding of WRAP53 $\beta$ to MDC1 and RNF8, a series of MDC1 internal deletion mutants were tested for binding to WRAP53 $\beta$ (Wang et al. 2011). This revealed that WRAP53 $\beta$ binds the phosphopeptide recognition FHA domain of MDC1 (amino acids 55-124), since deletion of this domain abolished their interaction, while deletion of the SDT repeats (amino acids 200-429) or the tandem BRCT domain (amino acids 1893-2089) of MDC1 did not alter binding to WRAP53 $\beta$ (Fig. 3B).

When mapping RNF8, we found that WRAP $53 \beta$ bind to its $\mathrm{N}$ terminus (containing the FHA domain) but not the middle part or $\mathrm{C}$ terminus of this protein /containing the RING domain) (Fig. 3C,D). Further deletion mapping identified a small section in the extreme $\mathrm{N}$ terminus of RNF8 (amino acids 1-38) critical for WRAP53 $\beta$ binding, since an internal deletion mutant of RNF8 lacking amino acids 39-109 retained the ability to bind WRAP53 $\beta$ (Fig. 3E).

The FHA domain of RNF8 is located between amino acids 13 and 140, encompassing an N-terminal phosphopeptide-binding part and an $\alpha$-helical extension (amino acids 130-140) that is located away from the phosphopeptide-interacting surface (Huen et al. 2007; Orthwein et al. 2014). A shorter variant of the RNF8 FHA (amino acids 17-111) has also been predicted (Mailand et al. 2007; Luijsterburg et al. 2012). We next explored whether WRAP53 $\beta$ and MDC1, which bind the FHA domain of RNF8 in a phosphorylation-dependent manner, target different regions of this domain. Indeed, while an $\mathrm{N}$ terminal version of RNF8 containing amino acids 1-140 was sufficient in binding both MDC1 and WRAP53 $\beta$, a shorter N-terminal variant of RNF8 (amino acids 1-111) bound only WRAP53 $\beta$, not MDC1 (Fig. 3D,F). Since deletion of amino acids 39-109 of RNF8 does not alter binding to WRAP53 $\beta$ but impairs binding to MDC1 (Fig.
3E), we conclude that the beginning of the RNF8 FHA domain (amino acids 1-38) mediates binding to WRAP53 $\beta$, while the end of the RNF8 FHA domain (amino acids 39140) is involved in binding MDC1 (Fig. 3G). Together, these data indicate that the FHA domains of both RNF8 and MDC1 mediate binding to WRAP53 $\beta$ and that these regions bound by WRAP53 $\beta$ are not involved in the direct interaction between RNF8 and MDC1.

\section{WRAP53 $\beta$ controls the interaction between RNF8 and phosphorylated MDC1}

To explore whether the scaffold protein WRAP53 $\beta$ regulates complex formation between RNF8 and MDC1, we first examined the organization of interactions between WRAP53 $\beta$, MDC1, RNF8, and $\gamma \mathrm{H} 2 \mathrm{AX}$. Knockdown H2AX, MDC1, and RNF8 and subsequent immunoprecipitation of WRAP53 $\beta$ revealed that interaction of WRAP53 $\beta$ with MDC1 is independent of RNF8 and H2AX, and interaction of WRAP53 $\beta$ with RNF8 is independent of MDC1 and H2AX (Fig. 4A). However, the interaction between MDC1 and RNF8 was clearly attenuated in irradiated cells depleted of WRAP53 $\beta$ (Fig. 4B).

Interaction between RNF8 and MDC1 is dependent on phosphorylation of MDC1 by ATM (Huen et al. 2007; Kolas et al. 2007; Mailand et al. 2007). To characterize the manner by which WRAP53 $\beta$ facilitates these interactions, we first examined whether WRAP53 $\beta$ affects phosphorylation of MDC1. Phosphorylated MDC1 migrated more slowly on an SDS gel than the unphosphorylated form (Stewart et al. 2003; Zhang et al. 2005), and preventing this phosphorylation by inhibition of ATM thus changed the mobility of the MDC1 band. In contrast, no such shift was observed when WRAP53 $\beta$ was knocked down (Fig. $4 C)$, suggesting that phosphorylation of MDC1 by ATM occurs independently of WRAP53 $\beta$ and, moreover, does 


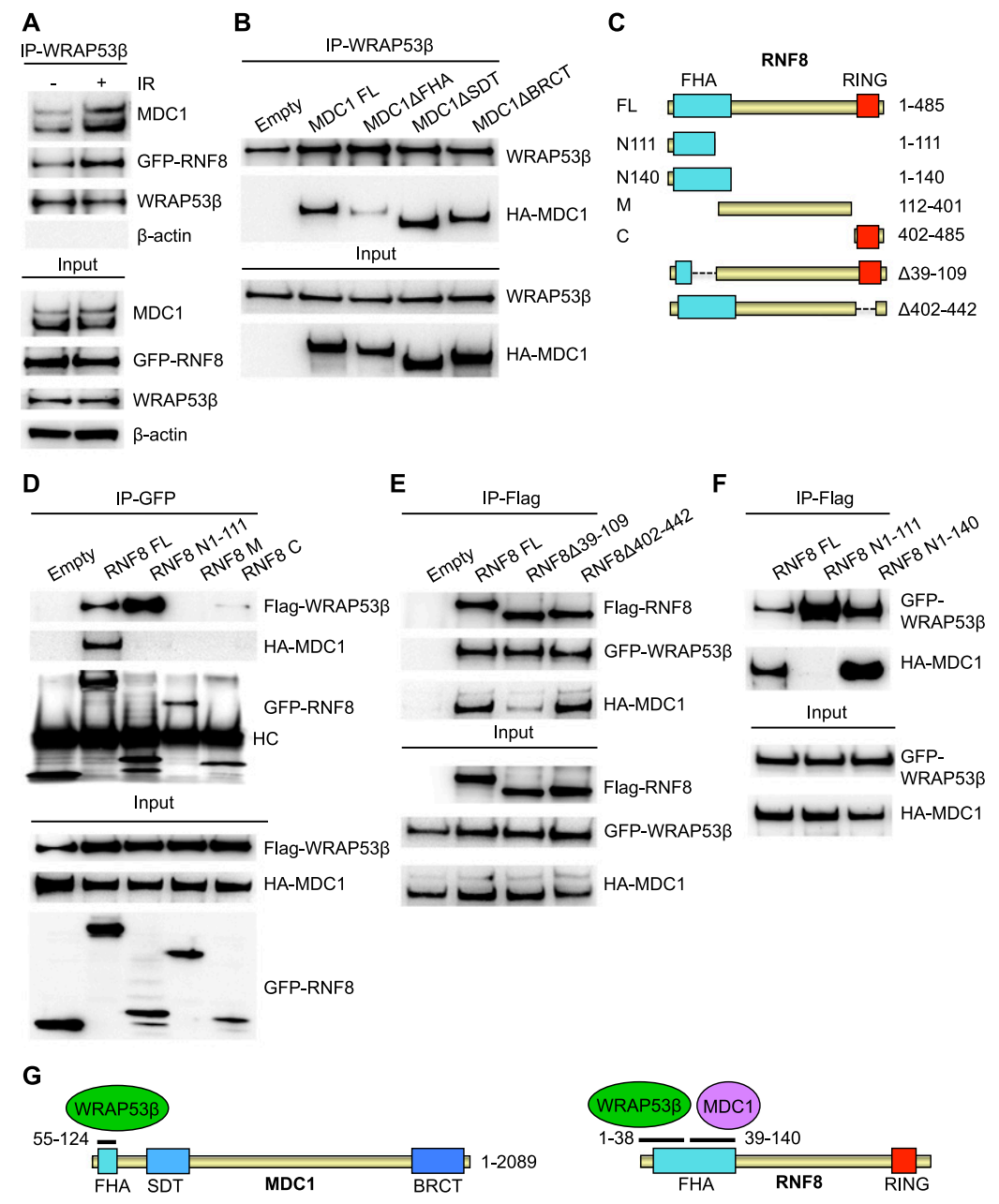

Figure 3. WRAP53 $\beta$ binds MDC1 and RNF8 via their FHA domains. (A) U2OS cells were either left untreated or irradiated with 6 Gy of IR, and, $30 \mathrm{~min}$, later immunoprecipitation of WRAP $53 \beta$ was performed, followed by immunoblotting of WRAP53 $\beta$, MDC1, GFP-RNF8, and $\beta$-actin. $(B)$ U2OS cells were transfected with the indicated HA-MDC1 constructs for $16 \mathrm{~h}$ and irradiated with $2 \mathrm{~Gy}$, and, 30 min later, immunoprecipitation of WRAP53 $\beta$ was performed, followed by immunoblotting of WRAP53 $\beta$ and HA-MDC1. $(C)$ Schematic illustration of RNF8 deletion constructs. (D) U2OS cells were transiently transfected with EGFP-RNF8 plasmids, HA-MDC1, and FlagWRAP53 $\beta$ for $16 \mathrm{~h}$; irradiated; and subjected to immunoprecipitation of GFP followed by immunoblotting for GFP-RNF8, Flag-WRAP53 $\beta$, and HA-MDC1. (HC) Heavy chain of the antibody. U2OS $(E)$ and H1299 $(F)$ cells were transiently transfected with Flag-RNF8 plasmids, HA-MDC1, and EGFP-WRAP53 $\beta$ for $16 \mathrm{~h}$; irradiated; and subjected to Flag immunoprecipitation followed by immunoblotting for the indicated proteins. $(G)$ Schematic illustration of the domain architecture of MDC1 and RNF8, where black lines mark WRAP53 $\beta$ - and MDC1-binding sites. Numbers indicate amino acids. not account for the loss of RNF8-MDC1 interaction in WRAP53 $\beta$-depleted cells.

To explore whether the WD40 domain of WRAP53 $\beta$ mediates MDC1-RNF8 interaction, a series of EGFPWRAP53 $\beta$ deletion constructs were generated (Fig. 4D). Indeed, the WD40 domain of WRAP53 $\beta$ proved to be both necessary and sufficient for binding both MDC1 and $\mathrm{RNF8}$, whereas the $\mathrm{N}$ or $\mathrm{C}$ terminus alone was unable to bind either of these factors (Fig. 4E). Moreover, introduction of the WD40 domain into cells transfected with WRAP53 $\beta$ siRNA restored 53BP1 focus formation, confirming that the WD40 domain of WRAP53 $\beta$ is critical for RNF8-mediated DNA DSB repair (Fig. 4F).

We further divided the WD40 domain of WRAP53 $\beta$ into different combinations of repeats (Supplemental Fig. 4A). Using these constructs, MDC1 and RNF8 were found to preferentially bind repeats 2 and 3 (Fig. 4G).

Missense mutations in WD40 repeats 1,5 , and 6 of WRAP53 $\beta$ cause the cancer predisposition syndrome dyskeratosis congenita and associate with nuclear exclusion and reduced expression of this protein (Zhong et al. 2011). These mutations were individually introduced into a vector encoding EGFP-WRAP53 $\beta$, and immunofluorescence confirmed a markedly reduced nuclear localization of these disease variants of WRAP53 $\beta$ (Supplemental Fig. 4A-C). Nevertheless, all mutants retained the ability to bind MDC1 and RNF8 (Supplemental Fig. 4D). Although these mutations localize outside of repeats 2 and 3, involved in binding MDC1 and RNF8, such WRAP53 $\beta$ mutants are excluded from the nucleus where MDC1 and RNF8 exert their function, indicating that interaction between these proteins likely is impaired in WRAP53 $\beta$ associated dyskeratosis congenita. Taken together, these findings demonstrate that, in response to DNA damage, WRAP53 $\beta$ binds MDC1 and RNF8 simultaneously via its WD40 domain, thereby facilitating interaction between these proteins and accumulation of RNF8 at DSBs (Fig. $4 \mathrm{H})$.

\section{WRAP53 $\beta$ promotes $H R$ and nonhomologous end-joining (NHEJ) repair}

Next, the impact of WRAP53 $\beta$ on repair of DSBs was evaluated by examining the clearance of $\gamma \mathrm{H} 2 \mathrm{AX}$ IRinduced foci (IRIF). Control cells showed a rapid induction of $\gamma \mathrm{H} 2 \mathrm{AX}$ foci following exposure to IR, and these foci were completely resolved $24 \mathrm{~h}$ after IR, indicating efficient DNA repair. Cells lacking WRAP53 $\beta$ showed 
A

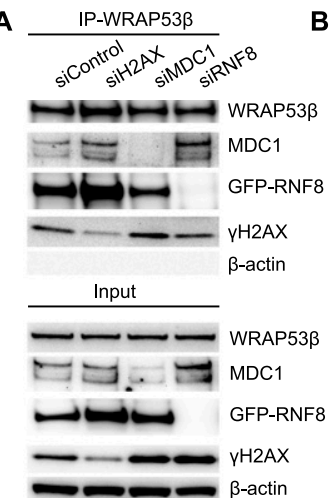

E
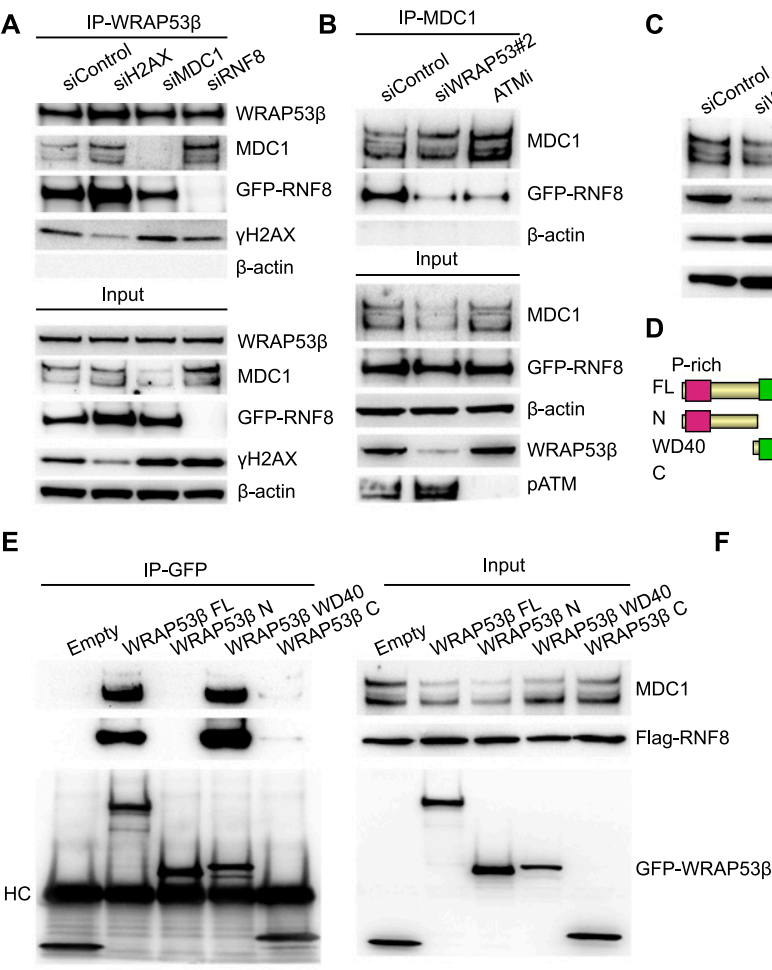

C

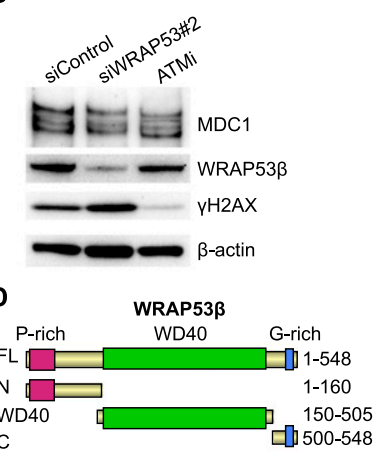

$\mathbf{F}$

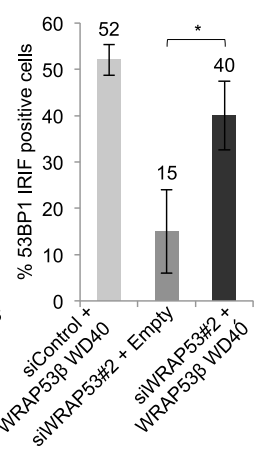

G

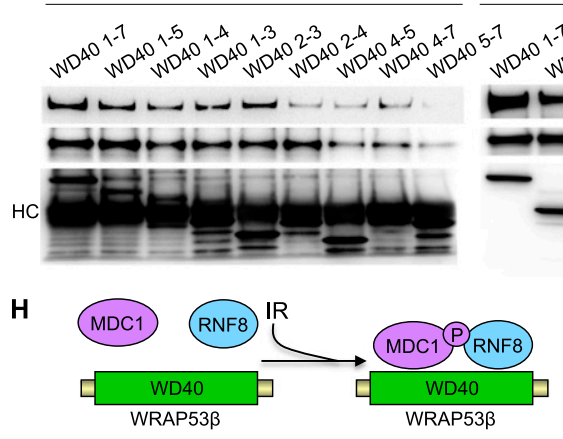

Input

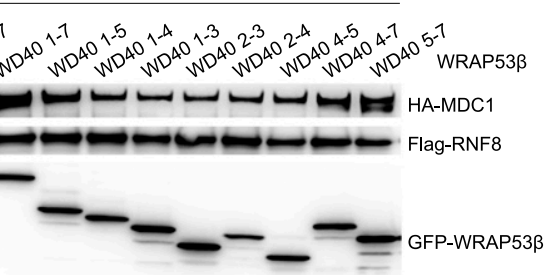

the same rapid induction of $\gamma \mathrm{H} 2 \mathrm{AX}$ foci $1 \mathrm{~h}$ after $\mathrm{IR}_{\text {; }}$ however, $24 \mathrm{~h}$ after IR, a significant amount of residual $\gamma \mathrm{H} 2 \mathrm{AX}$ foci still remained (Fig. 5A,B), indicating defective repair. RNF8 depletion affected residual $\gamma \mathrm{H} 2 \mathrm{AX}$ foci in the same manner as WRAP53 $\beta$ deficiency (Fig. 5A,B). Western blotting confirmed elevated $\gamma \mathrm{H} 2 \mathrm{AX}$ levels in cells depleted of WRAP53 $\beta 24 \mathrm{~h}$ after IR (Supplemental Fig. 5A). Persisting foci following WRAP53 $\beta$ depletion were not linked to its known interaction partner, coilin, since knockdown of coilin did not influence the formation of $\gamma \mathrm{H} 2 \mathrm{AX}$ foci either with or without IR (Fig. 5A,B; Supplemental Fig. 5B; data not shown). Moreover, since U2OS cells lack telomerase, the involvement of WRAP53 $\beta$ in DNA repair appears to be independent of this enzyme. Indirect effects on apoptosis were also excluded (Supplemental Fig. 5C). In addition, pulse-field gel electrophoresis demonstrated that stimulation of $\mathrm{H} 2 \mathrm{AX}$ phosphorylation
Figure 4. WRAP53 $\beta$ facilitates MDC1-RNF8 interaction through its WD40 domain. (A) U2OS cells were treated with the siRNAs indicated for $48 \mathrm{~h}$ and with GFP-RNF8 for $24 \mathrm{~h}$ (all samples), irradiated with $6 \mathrm{~Gy}$, and, 30-min later, subjected to immunoprecipitation of WRAP $53 \beta$ followed by immunoblotting of WRAP53 $\beta$, MDC1, RNF8, $\gamma \mathrm{H} 2 \mathrm{AX}$, and $\beta$-actin. $(B)$ Immunoprecipitation of $\mathrm{MDC1}$ in irradiated (6 Gy, 15-min recovery) U2OS cells treated with the siRNA indicated for $48 \mathrm{~h}$ or ATM inhibitor (ATMi) for $24 \mathrm{~h}$. All samples were transfected with GFP-RNF8 for $16 \mathrm{~h}$. (C) U2OS cells were treated with the siRNAs indicated for $48 \mathrm{~h}$ or ATM inhibitor for $16 \mathrm{~h}$, irradiated with $6 \mathrm{~Gy}$, allowed to recover for $15 \mathrm{~min}$, and then subjected to Western blotting of MDC1, WRAP53 $\beta, \gamma \mathrm{H} 2 \mathrm{AX}$, and $\beta$-actin. (D) Schematic illustration of EGFP-tagged deletion constructs of WRAP53 $\beta$. (E) U2OS cells were transiently transfected with the indicated EGFPWRAP53 $\beta$ plasmids and Flag-RNF8 for $16 \mathrm{~h}$, irradiated, and subjected to GFP immunoprecipitation followed by immunoblotting for MDC1, Flag-RNF8, and GFP-WRAP53ß. (HC) Heavy chain of the antibody. $(F)$ U2OS cells were transfected with siControl or siWRAP53\#2 oligonucleotides for $8 \mathrm{~h}$ followed by transfection of EGFP-Empty or EGFP-WRAP53 $\beta$ WD40 (1-7) for $16 \mathrm{~h}$, exposed to IR (6 Gy), and, after $1 \mathrm{~h}$, immunostained for 53BP1 followed by quantification of the results. The graph in $A$ shows the percentage of 100 GFP transfected cells in each experiment whose nuclei were 53BP1-positive. The error bars depict the SEM. $n=3 ;\left(^{*}\right) P<0.05$, as determined by Student's $t$-test. $(G) \mathrm{U} 2 \mathrm{OS}$ cells were transiently transfected with the indicated EGFP-WRAP53 $\beta$ plasmids, HAMDC1, and Flag-RNF8 for $16 \mathrm{~h}$; irradiated; and subjected to immunoprecipitation of GFP followed by immunoblotting for HA-MDC1, Flag-RNF8, and GFP-WRAP53 $\beta$. $(H)$ Schematic illustration of how WRAP53 $\beta$ scaffolds the MDC1-RNF8 complex. Upon DNA damage, WRAP53 $\beta$ binds MDC1 and RNF8 simultaneously via its WD40 domain and facilitates their interaction. by IR of WRAP53 $\beta$-depleted cells was due to accumulation of DNA breaks (Supplemental Fig. 5D). To determine whether depletion of WRAP53 $\beta$ renders cells sensitive to IR, clonogenic survival assays were performed. However, since prolonged silencing of WRAP $53 \beta$ triggered massive apoptosis and a $80 \%-95 \%$ reduction in colony formation in nonirradiated H1299 and U2OS cells (data not shown), these experiments were inconclusive.

To assess the involvement of WRAP53 $\beta$ in DSB repair, we used GFP reporter assays for the HR and NHEJ repair pathways. The HR assay was based on U2OS cells carrying the DR-GFP construct, in which expression of exogenous I-SceI introduces a single DSB. Repair of this break by HR creates a functional GFP gene, and its expression level is an accurate readout for HR efficiency (Pierce et al. 1999). Strikingly, this revealed that WRAP53 $\beta$ knockdown lowered HR by $74 \%$, which is comparable 
A

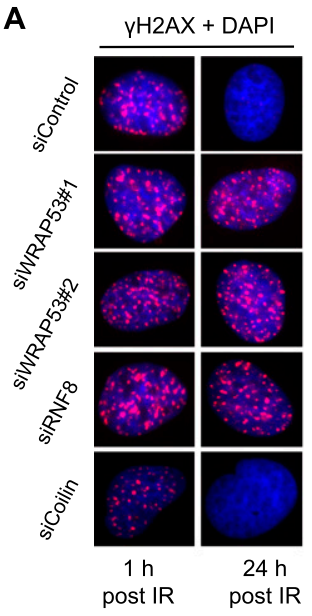

C

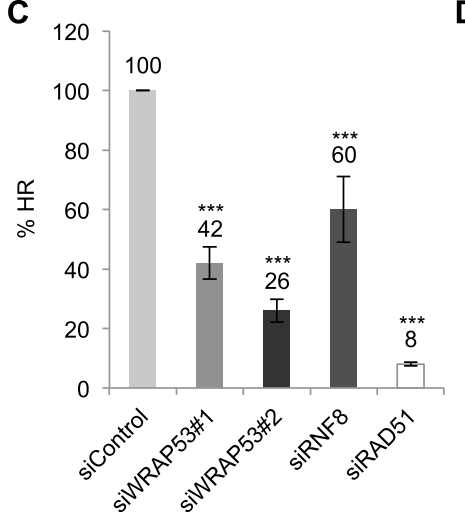

B

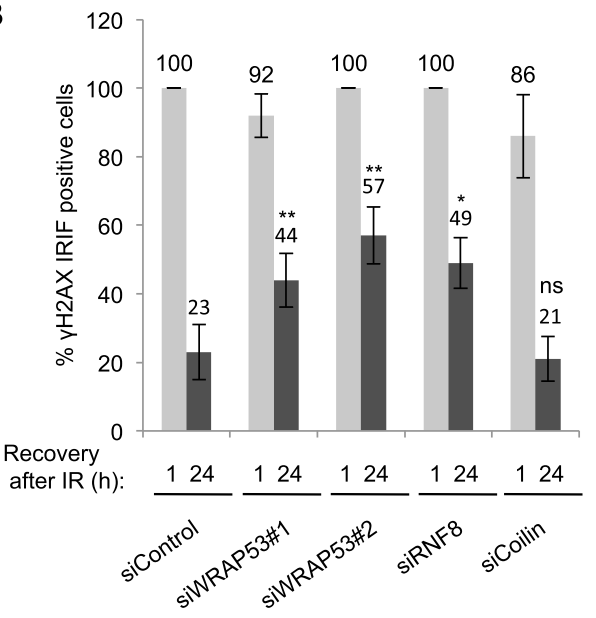

D

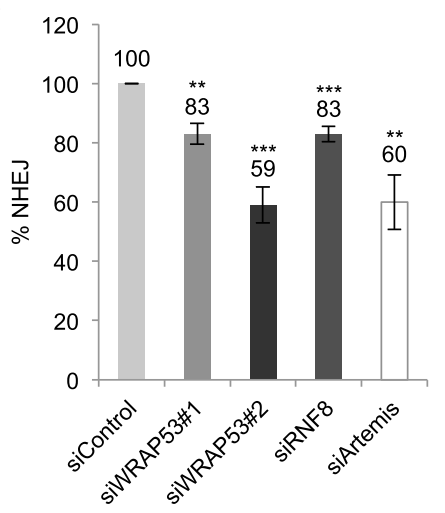

Figure 5. WRAP53 $\beta$ promotes HR and NHEJ. $(A)$ U2OS cells were treated with the siRNAs indicated for $24 \mathrm{~h}$, exposed to 6 Gy of IR, fixed $1 \mathrm{~h}$ or $24 \mathrm{~h}$ later, and immunostained for $\gamma \mathrm{H} 2 \mathrm{AX}$. $(B)$ Quantification of the results in $A$ showing the percentage of nuclei containing $>10 \gamma \mathrm{H} 2 \mathrm{AX}$ foci $(n=200) .(C, D) \mathrm{HR}(C)$ and NHEJ $(D)$ efficiency following treatment of the cells with the siRNA indicated for $48 \mathrm{~h}$. DR-GFP (HR) and EJ5-GFP (NHEJ) reporter systems were used in the FACS analysis, with siRAD51 and siArtemis as positive controls. (E) Cells were transfected with siRNA for $24 \mathrm{~h}$, exposed to IR ( $3 \mathrm{~Gy}$ ), harvested at the time points indicated, and subjected to flow cytometry. Nonirradiated cells were treated with siRNA alone for $60 \mathrm{~h}$. The error bars depict the SEM. $n=3 ;\left(^{\star}\right) P<0.05 ;\left(^{\star \star}\right) P<0.01 ;\left(^{\star \star \star}\right) P<$ 0.001 , as determined by Student's $t$-test.

E

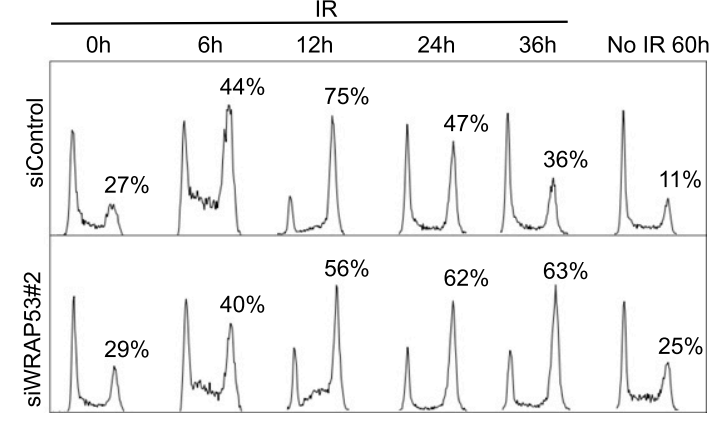

with the $92 \%$ reduction obtained upon depleting RAD51, a known component of HR. RNF8 silencing resulted in a $40 \%$ reduction in the efficiency of $\mathrm{HR}$ (Fig. 5C). The NHEJ assay worked in a fashion similar to the HR assay but used a GFP reporter (EJ5-GFP) with two I-SceI sites flanking a puro gene. Following I-SceI cleavage, the puro gene was removed, and repair of these DSBs by NHEJ placed a promoter adjacent to the GFP gene and allowed expression of GFP (Gunn and Stark 2012). We found that NHEJ repair was attenuated $41 \%$ and $17 \%$ by knockdown of WRAP53 $\beta$ and RNF8, respectively (Fig. 5D). Depletion of Artemis, a key component of NHEJ, decreased this repair by $40 \%$. Notably, depletion of WRAP $53 \beta$ had a more profound effect on HR and NHEJ compared with knockdown of RNF8. Moreover, codepletion of WRAP53 $\beta$ and
RNF8 did not further impair HR or NHEJ repair as compared with knocking down WRAP53 $\beta$ alone (Supplemental Fig. 5E). This suggests that RNF8 acts in the same pathway as WRAP53 $\beta$, while WRAP53 $\beta$ plays additional roles in DNA DSB repair.

To gain further insight into WRAP53 $\beta$-mediated DDR effects, we studied cell cycle progression in WRAP53 $\beta$ depleted cells in combination with IR. In the presence of DNA damage, the cell cycle is delayed to allow more time for repair. WRAP53 $\beta$-depleted cells exposed to IR demonstrated normal G2/M checkpoint activation but a prolonged G2/M arrest, suggesting delayed recovery due to defective DNA repair (Fig. 5E). Thus, WRAP53 $\beta$ plays a key role in both HR and NHEJ repair of DSBs, and, in its absence, DNA breaks accumulate, and checkpoint activation persists. 
WRAP53 $\beta$ protects cells against spontaneous DNA damage

We observed that siRNA-mediated knockdown of WRAP53 $\beta$ in U2OS cells elevated the number of $\gamma \mathrm{H} 2 \mathrm{AX}$ foci in nonirradiated cells within $24 \mathrm{~h}$, indicating accumulation of spontaneous DNA damage (Fig. 6A,B). Moreover, depletion of RNF8 elevated spontaneous formation of $\gamma \mathrm{H} 2 \mathrm{AX}$ foci in a similar manner (Supplemental Fig. $6 A)$. Prolonged silencing of WRAP53 $\beta$ (48-72 h) was associated with more spontaneous $\gamma \mathrm{H} 2 \mathrm{AX}$ foci and apoptosis apparent from $72 \mathrm{~h}$ after siRNA treatment (Fig. 6B; Supplemental Fig. 6B). Western blotting of $\gamma \mathrm{H} 2 \mathrm{AX}$ levels confirmed its increased phosphorylation following WRAP53 $\beta$ depletion (Supplemental Fig. 6C). A similar phenomenon was seen in H1299 and HeLa cells (Supplemental Fig. 6D-F). Both alkaline and neutral comet assays revealed that cells lacking WRAP53 $\beta$ contain larger numbers of sporadic DNA breaks (Fig. 6C; Supplemental Fig. 6G). Thus, we conclude that WRAP $53 \beta$ protects cells against spontaneous DNA damage. The fact that WRAP53 $\beta$ knockdown triggers spontaneous activation of $\gamma \mathrm{H} 2 \mathrm{AX}$ in $\mathrm{H} 1299$ and HeLa cells, which lack and have inactivated p53, respectively, demonstrates that the role played by WRAP $53 \beta$ in the protection against spontaneous DNA damage is independent of WRAP53 $\alpha$-mediated regulation of p53. Taken together with our other findings, these results suggest that WRAP53 $\beta$ plays an essential role in the DDR and that attenuation of this function disturbs repair of DSBs and leads to accumulation of spontaneous DNA breaks, which are considered to be the major factor underlying genomic instability.

\section{Discussion}

The present investigation identifies the scaffold protein WRAP $53 \beta$ as a novel regulator of DSB repair that orchestrates the assembly of repair factors at such sites of DNA damage. In response to IR, WRAP $53 \beta$ is recruited to DNA breaks in an ATM-, H2AX-, and MDC1-dependent manner. Our findings reveal that WRAP53 $\beta$ targets the critical ubiquitin ligase RNF8 to DNA lesions by promoting MDC1-RNF8 interactions. Accordingly, WRAP53 $\beta$ is required for efficient ubiquitylation of damaged chromatin, an important aspect of the signaling and repair of DNA damage (Fig. 7). Consequently, loss of WRAP53 $\beta$ disrupts DNA repair by both HR and NHEJ and leads to accumulation of DSBs, consistent with attenuated accumulation and activity of RNF8 at these breaks (Meerang et al. 2011).

In the DDR recruitment cascade, RNF8 acts immediately downstream from MDC1. ATM-mediated phosphorylation of MDC1 generates binding sites recognized by the FHA domain of RNF8, which is critical for the targeting of RNF8 to DNA breaks (Huen et al. 2007; Kolas et al. 2007; Mailand et al. 2007). In agreement with previous reports, we found that localization of RNF8 to DSBs is dependent on its interaction with MDC1. In WRAP53 $\beta$-depleted cells, IR did not induce the formation of RNF8 foci, and, indeed, interaction between RNF8 and MDC1 was disrupted. The loss of binding between RNF8 and MDC1 was not due to abrogated MDC1 phosphorylation, since hyperphosphorylation of MDCl was observed even when WRAP53 $\beta$ was knocked down. Moreover, assembly of MDC1 at DSBs was normal in WRAP53 $\beta$ depleted cells. Instead, our present observations suggest that WRAP $53 \beta$ promotes the accumulation of RNF8 to sites of DNA damage by tethering MDC1 and RNF8 together. WRAP53 $\beta$ contains a WD40 domain, a highly conserved and well-established domain for protein interactions. We show here that in response to DNA damage, simultaneous binding of MDC1 and RNF8 to this region is required for their interaction. In this respect, WRAP53 $\beta$ appears to function as a scaffold for stable MDC1-RNF8 complex formation, thereby supporting the formation of RNF8 IRIF and subsequent ubiquitin-dependent assembly
A

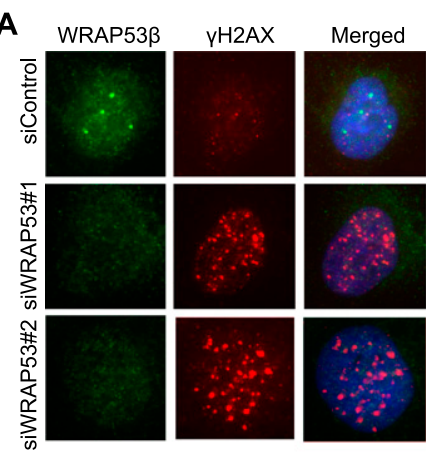

B

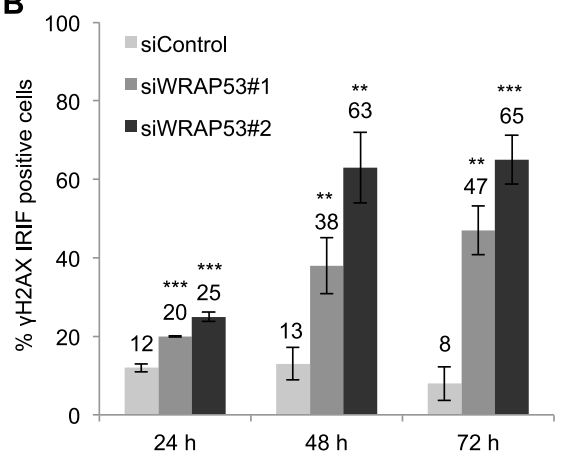

Figure 6. WRAP53 $\beta$ protects cells against accumulation of spontaneous DNA damage. $(A)$ U2OS cells were treated with siControl or two different siWRAP53 oligonucleotides (siWRAP53\#1 and siWRAP53\#2) for $24 \mathrm{~h}$, fixed, and immunostained for WRAP53 $\beta$ and $\gamma \mathrm{H} 2 \mathrm{AX}$. $(B)$ The percentage of nuclei in $A$ containing $>10 \gamma \mathrm{H} 2 \mathrm{AX}$ foci was quantified in the 200 cells counted for each experiment. (C) After treating U2OS with siWRAP53\#2 or siControl for $24 \mathrm{~h}$ or $48 \mathrm{~h}$, DNA damage was assessed by the alkaline comet assay. The error bars depict the SEM. $n=3 ;\left(^{\star \star}\right) P<0.01 ;\left(^{\star \star \star}\right) P<$ 0.001 , as determined by Student's $t$-test.

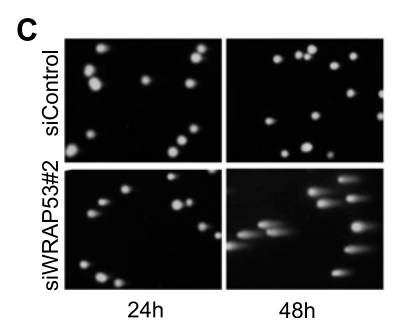




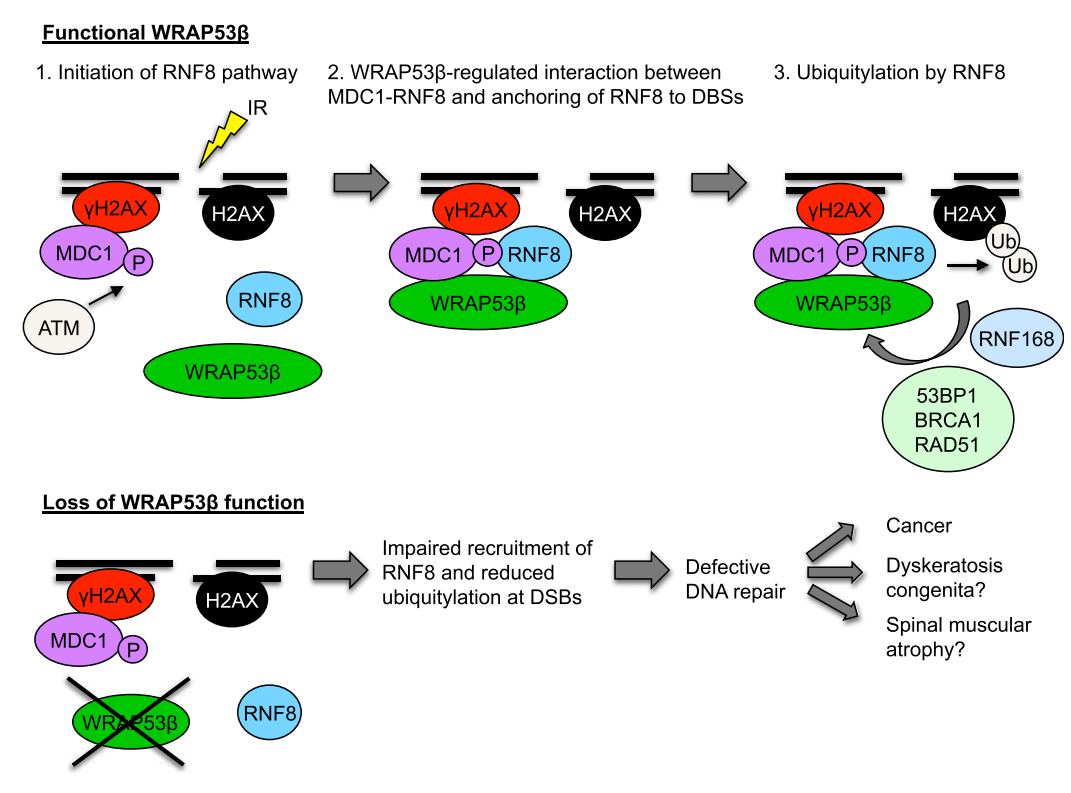

Figure 7. Schematic model of WRAP53 $\beta$ function in the DDR pathway. (Step 1) In response to IR, $\gamma \mathrm{H} 2 \mathrm{AX}$ and MDC1 accumulate at DSBs independently of WRAP53 $\beta$. ATM-mediated phosphorylation of MDC1 makes MDC1 competent to bind RNF8. However, RNF8 is not yet localized at DSBs. (Step 2) WRAP53 $\beta$ is recruited to sites of DNA damage in an ATM-, H2AX-, and MDC1dependent manner. Simultaneous binding of MDC1 and RNF8 to WRAP53 $\beta$ facilitates their direct interaction and retention of RNF8 at DSBs. (Step 3) Once assembled at DSBs, RNF8 catalyzes ubiquitylation of H2AX. Ubiquitylation at DSBs enables recruitment and accumulation of 53BP1, BRCA1, and RAD51 and subsequent DNA repair. of downstream repair factors. Thus, the proper accumulation and functioning of RNF8 at DNA DSBs appear to be regulated via both phosphorylation of $\mathrm{MDC1}$, which enables direct binding between MDC1 and RNF8, and WRAP53 $\beta$, which scaffolds and stabilizes the MDC1RNF8 interaction. Similarly, we demonstrated previously that WRAP $53 \beta$ controls assembly of the survival of motor neuron (SMN) protein in Cajal bodies by mediating the direct interaction between SMN and the coilin protein (Mahmoudi et al. 2010).

This role of WRAP53 $\beta$ in the DDR bears striking similarities to the function of another WD40 protein, PALB2. In response to DNA damage, PALB2 facilitates interaction between BRCA1 and BRCA2 and the subsequent anchoring of BRCA2 to sites of DNA damage (Xia et al. 2006). Although PALB2 binds both of these proteins even in the absence of DNA damage, it promotes their interaction and localization of BRCA2 to DSBs only after the induction of DNA damage by IR, whereas BRCA1 localizes to DSBs independently of PALB2, where it helps recruit PALB2 to these sites (Zhang et al. 2009). In the same manner, WRAP53 $\beta$ facilitates MDC1 and RNF8 interaction, controlling the accumulation of RNF8 only at DSBs, whereas MDC1 form IRIF independently of WRAP $53 \beta$ and help recruit WRAP53 $\beta$ to DSBs.

We show that WRAP53 $\beta$ binds the FHA domains of both MDC1 and RNF8, a domain known to primarily mediate phosphorylation-dependent protein interactions with a high specificity toward phosphorylated threonines. However, phosphorylation-independent interactions mediated by FHA domains have also been described. The FHA domain of MDC1 has been shown to bind Thr68-phosphorylated Chk2, Ser1981-phosphorylated ATM, and unphosphorylated RAD51 (Coster and Goldberg 2010), while the same domain of RNF8 binds phosphorylated MDC1 and CHD4 independent of phosphorylation (Huen et al. 2007; Kolas et al. 2007; Mailand et al. 2007; Luijsterburg et al. 2012). The phosphorylation-independent interaction between RNF8-FHA and CHD4 excludes the $\alpha$-helical extension of RNF8 (amino acids 130-140) (Luijsterburg et al. 2012). Similarly, mutants of RNF8 either lacking its $\alpha$-helical extension (N1-111) or with an inactivated FHA domain $(\Delta 39-109)$ still bound WRAP $53 \beta$, suggesting that WRAP53 $\beta$ also interacts with the RNF8 FHA domain independently of phosphorylation and the $\alpha$-helical extension. We also show that WRAP53 $\beta$ targets the extreme $\mathrm{N}$ terminus of RNF8-FHA, while MDC1 binds to downstream parts of this same domain, enabling their simultaneous interaction with RNF8. Thus, our present investigation suggests that the FHA domains of MDC1 and RNF8 target sites within the WD40 domain of WRAP53 $\beta$, but whether this requires phosphorylation of WRAP53 $\beta$ remains to be investigated.

Many DDR proteins, especially those involved in the initial steps in the DSB signaling cascade, also participate in telomere maintenance (d'Adda di Fagagna et al. 2004). Our current study establishes that WRAP53 $\beta$ also both acts at telomeres and is involved in the DDR pathway. This raises the interesting possibility that WRAP53 $\beta$ might regulate telomere elongation and DNA repair via a common mechanism. Indeed, it is known that WRAP53 $\beta$ maintains telomeres by recruiting the telomerase enzyme to telomeres (Venteicher et al. 2009). However, the role of WRAP53 $\beta$ in DNA repair must be independent of telomerase and distinct from its involvement in telomere maintenance, since the U2OS cells characterized here do not express telomerase but instead maintain their telomeres by alternative lengthening of telomeres (ALT). Moreover, depletion of coilin, which interacts with WRAP53 $\beta$, did not disrupt DNA repair in the same manner as knocking down WRAP53 $\beta$ itself. Since coilin has previously been implicated in NHEJ repair (Velma et al. 2010), WRAP53 $\beta$ may act upstream of coilin, which would explain why its loss results in more extensive DDR defects.

We observed that knockdown of WRAP53 $\beta$ consistently enhanced the level of spontaneous DNA breaks. 
HR eliminates such lesions formed during the process of DNA replication. Accordingly, cells deficient in proteins involved in this repair mechanism, such as BRCA1, exhibit high levels of sporadic DNA damage /Venkitaraman 2002; Saleh-Gohari et al. 2005; Petermann and Helleday 2010). These considerations are consistent with the involvement of WRAP53 $\beta$ in HR and also suggest that reduced expression of this protein may contribute to genomic instability and carcinogenesis. Consistent with this hypothesis, we found that lack or low levels of WRAP $53 \beta$ correlated with reduced patient survival and attenuated DDR in $\sim 400$ ovarian cancer patients (data not shown). This indicates that loss of WRAP $53 \beta$-mediated DNA repair contributes to the formation and/or progression of tumors.

Germline mutations in WRAP $53 \beta$ result in dyskeratosis congenita, which is characterized by premature aging and a predisposition to develop cancer. Such mutations patently reduce nuclear expression of WRAP $53 \beta$ and lead to progressive shortening of telomeres due to impaired WRAP $53 \beta$-mediated trafficking of telomerase in cells from these patients (Zhong et al. 2011). Similarly, patients with spinal muscular atrophy, a neurodegenerative disorder, exhibit functional loss of nuclear WRAP53 $\beta$. Our discovery that WRAP $53 \beta$ is a key component of the DDR suggests that defects in DNA repair may also contribute to the manifestations of these diseases, although this remains to be shown.

In summary, the present investigation establishes WRAP $53 \beta$ as a novel regulator of DSB repair, serving as a platform for the formation of protein complexes involved in the DDR. Indeed, our findings highlight the role of scaffold proteins in various aspects of this response. Moreover, in light of its additional participation in telomerase trafficking, WRAP53 $\beta$ appears to play a major role in guiding enzymes responsible for the restoration and maintenance of genome integrity. Our model suggests a potentially important novel mechanism underlying the defects in DNA repair associated with neurodegeneration, aging, and cancer and may thus have far-reaching clinical and therapeutic implications.

\section{Materials and methods}

\section{Cells and culture conditions}

U2OS cells were maintained in McCoy's 5A medium (HyClone, Thermo Scientific); fibroblasts were kept in minimum essential medium (HyClone, Thermo Scientific); and U2OS (DR-GFP and EJ5-GFP), H1299, and HeLa cells were maintained in Dulbecco's modified Eagle medium (DMEM) (HyClone, Thermo Scientific) supplemented with $10 \%$ fetal bovine serum (FBS) (HyClone) and $2.5 \mu \mathrm{g} / \mathrm{mL}$ plasmocin (InvivoGen) at $37^{\circ} \mathrm{C}$ in $5 \% \mathrm{CO}_{2}$ humidified incubators. MCF7 cells stably expressing ddI-PpoI were grown in DMEM supplemented with $10 \%$ FBS $+1 \mu \mathrm{g} / \mathrm{mL}$ puromycin (Sigma). 4-OHT (Sigma) was added to a final concentration of $1 \mu \mathrm{M}$. Shield-1 (Cheminpharma) was added to a final concentration of $1 \mu \mathrm{M}$ for $3 \mathrm{~h}$ to stabilize the ddI-PpoI fusion protein. MCF7 cells were arrested in G1 phase of the cell cycle, in which NHEJ should be the predominant DSB repair mechanism, by cultivating them in medium containing $0.1 \%$ FBS for $24 \mathrm{~h}$ before DSB induction.
Laser microirradiation

Localized DNA damage was generated by exposure of cells to a UV-A laser. Fibroblasts and U2OS and H1299 cells were presensitized with $10 \mathrm{mM}$ 5-bromo-2'-deoxyuridine (BrDU) for $24 \mathrm{~h}$ at $37^{\circ} \mathrm{C}$. Prior to microscopy, the medium was replaced for a phenol red-free medium. Microirradiation was performed with a confocal microscope equipped with a 365 -nm UV-A laser.

\section{$I R$}

$\gamma$-Irradiation was performed with a ${ }^{137} \mathrm{Cs}$ source (Scanditronix) at the Karolinska Institutet, Stockholm, at a photon dose rate of 0.5 $\mathrm{Gy} / \mathrm{min}$. Dosimetry was done with an ionization chamber as well as with ferro-sulphate.

\section{Immunofluorescence microscopy}

Cells were grown on sterilized coverslips and fixed with $4 \%$ paraformaldehyde (PFA) for $15 \mathrm{~min}$ at room temperature. They were then permeabilized with $0.1 \%$ Triton X-100 for 5 min at room temperature followed by $30 \mathrm{~min}$ of blocking in blocking buffer (2\% BSA, 5\% glycerol, $0.2 \%$ Tween $20,0.1 \% \mathrm{NaN}_{3}$ ). Coverslips were subsequently incubated for $1 \mathrm{~h}$ in primary antibody and $40 \mathrm{~min}$ in secondary antibody diluted in blocking buffer. The coverslips were mounted with VectaShield mounting medium with DAPI (Vector Laboratories). Images were acquired with a Zeiss Axioplan 2 microscope equipped with an AxioCam HRm Camera using a $40 \times$ or $63 \times$ oil immersion lens and processed using Axiovision release 4.7.

Pre-extraction To visualize WRAP53 $\beta$ IRIF, the cells were first washed with PBS; incubated for $3 \mathrm{~min}$ at room temperature with cytoskeleton (CSK) buffer containing $10 \mathrm{mM}$ pipes (pH 7.0), 100 $\mathrm{mM} \mathrm{NaCl}, 300 \mathrm{mM}$ sucrose, $3 \mathrm{mM} \mathrm{MgCl}$, and $0.7 \%$ Triton $\mathrm{X}-100$; and thereafter incubated for another $3 \mathrm{~min}$ with the same CSK buffer supplemented with $0.3 \mathrm{mg} / \mathrm{mL}$ RNase A (CSK+R). After these treatments, the cells were washed once again with PBS and then fixed in $4 \%$ PFA.

\section{Antibodies}

The WRAP53 $\beta$ antibodies used were rabbit $\alpha$-WRAP53-C2 (used for Western blot, immunoprecipitation, ChIP, and immunofluorescence experiments; Innovagen AB, catalog no. PA-2020-100), rabbit $\alpha$-WDR79 (used for immunofluorescence; Bethyl Laboratories, catalog no. A301-442A-1), rabbit $\alpha$-WRAP53 (used for immunofluorescence; Proteintech, catalog no. 14761-1-AP), rabbit $\alpha$-WDR79 (used for immunofluorescence; Abnova, catalog no. H00055135-D01P), mouse monoclonal $\alpha$-WDR79 (clone 1F12; used for immunofluorescence; Abnova, catalog no. H00055135M04), and mouse polyclonal $\alpha$-WDR79 (used for immunofluorescence; Abnova, catalog no. H00055135-B01P).

The following antibodies were used in immunoprecipitation, immunofluorescence, and Western blots: mouse $\alpha-\gamma \mathrm{H} 2 \mathrm{AX}$ (Millipore, catalog no. 05-636), rabbit $\alpha-\gamma \mathrm{H} 2 \mathrm{AX}$ (Cell Signaling, catalog no. 2577), rabbit $\alpha-H 2 A X$ (Abcam, catalog no. ab11175), rabbit $\alpha$-MDC1 (Abcam, catalog no. ab11169), mouse $\alpha-M D C 1$ (Abcam, catalog no. ab50003), mouse $\alpha$-pATM (Santa Cruz Biotechnology, catalog no. sc-47739), mouse $\alpha$-RNF8 (Santa Cruz Biotechnology, catalog no. sc-271462), rabbit $\alpha$-RNF8 (provided by Michael Huen), rabbit $\alpha$-RNF168 (Millipore, catalog no. ABE367), mouse $\alpha$-ubiquitin (FK2; Calbiochem, catalog no. ST1200), rabbit $\alpha-53$ BP1 (Novus Biologicals, catalog no. NB100-904), mouse $\alpha$-BRCA1 (Santa Cruz Biotechnology, catalog no. sc-6954), rabbit $\alpha$-RAD51 (Santa Cruz Biotechnology, catalog no. sc-8349), rabbit $\alpha$-coilin (Santa Cruz Biotechnology, 
catalog no. sc-32860), mouse $\alpha-\beta$-actin (Sigma), rabbit $\alpha$-GFP (Abcam, catalog no. ab290), mouse $\alpha$-Flag (Agilent Technologies, catalog no. 200472-21), normal rabbit IgG (Santa Cruz Biotechnology, catalog no. sc-2027), and normal mouse IgG (Santa Cruz Biotechnology, catalog no. sc-2025). The secondary antibodies used were sheep $\alpha$-mouse HRP (GE Healthcare, catalog no. NA931V), donkey $\alpha$-rabbit HRP (GE Healthcare, catalog no. NA934V), goat $\alpha$-rabbit HRP (Cell Signal, catalog no. 7074), horse $\alpha$-mouse HRP (Cell Signal, catalog no. 7076), goat $\alpha$-rabbit Alexa Fluor 488 (Invitrogen, catalog no. A11008), goat $\alpha$-mouse Alexa Fluor 488 (Invitrogen, catalog no. A11029), and donkey $\alpha$-mouse Alexa Fluor 594 (Invitrogen, catalog no. A21203).

\section{siRNA transfections}

The siRNA oligonucleotides used were siWRAP53\#1 (Qiagen, catalog no. SI00388941), siWRAP53\#2 (Qiagen, catalog no. SI00388948), siH2AX (Qiagen, catalog no. SI00032844), siMDC1 (Dharmacon, catalog no. L-003506-00-0005), siRNF8 (Dharmacon, catalog no. L-006900-00-0005), siRAD51 (Qiagen, catalog no. SI02663682), siCoilin (Qiagen, catalog no. SI00350343), siArtemis (Qiagen, catalog no. SI00133945), and siControl (Qiagen, catalog no. 1027280). siRNA (10-20 nM) was transfected into cells using HiPerfect (Qiagen) transfection reagent in accordance with the supplier's recommendations.

\section{Treatment with small-molecule inhibitors}

ATM (KU55933) and DNA-PK (NU7441) inhibitors were obtained from TOCRIS bioscience. The ATR inhibitor (VE-821) was obtained from Axon MedChem (catalog no. Axon 1893). Where appropriate, $10 \mu \mathrm{M}$ ATM inhibitor, $2 \mu \mathrm{M}$ DNA-PK inhibitor, and $2.5 \mu \mathrm{M}$ ATR inhibitor were added to the culture medium $6-24 \mathrm{~h}$ prior to IR.

\section{ChIP}

The ChIP protocol was adapted for use with magnetic beads (Dynabeads M-280 sheep anti-rabbit, Invitrogen). MCF7 cells expressing ddI-PpoI were treated with Shield-1 for $3 \mathrm{~h}$ followed by 4-OHT and were collected for ChIP. Immunoprecipitations were first washed in low-salt wash $(150 \mathrm{mM} \mathrm{NaCl}, 0.1 \%$ SDS, $1 \%$ Triton X-100, 2 mM EDTA, $20 \mathrm{mM}$ Tris-HCl), followed by high-salt wash $(500 \mathrm{mM} \mathrm{NaCl}, 0.1 \%$ SDS, $1 \%$ Triton X-100, 2 mM EDTA, $20 \mathrm{mM}$ Tris-HCl), followed by three washes in $\mathrm{LiCl}$ wash $\left(0.25 \mathrm{M} \mathrm{LiCl}, 1 \%\right.$ IGEPAL $^{\star \star}$, $1 \%$ deoxycholic acid, $1 \%$ IGEPAL, $10 \mathrm{mM}$ Tris-HCl). Washes were performed by rotation for $5 \mathrm{~min}$ at room temperature. An appropriate negative control using normal rabbit IgG was performed for the ChIP experiment.

\section{Plasmids}

Plasmid transfections were performed using Lipofectamine 2000 reagent (Life Technologies) according to the manufacturer's recommendations. To generate EGFP or 3xFlag-tagged WRAP53 $\beta$ and RNF8 constructs, inserts were amplified by PCR (Advantage 2 polymerase, Clontech) and subcloned into pEGFP-C1 (Clontech) or p3XFlag-CMV10 (Sigma, catalog no. E7658) expression vectors. All primers used for PCR amplifications are listed in Supplemental Table 1.

\section{Statistical analysis}

The analyses were performed using Microsoft Excel 2011. Two-tailed Student's $t$-test was used to determine statistical significance.

\section{Western blotting}

For cell extracts for Western blot analysis, cells were harvested, washed, and lysed in ice-cold Western blot lysis buffer $100 \mathrm{mM}$ Tris-HCL at $\mathrm{pH} 8,150 \mathrm{mM} \mathrm{NaCl}, 1 \%$ NP-40, 1\% PMSF, $1 \%$ protease inhibitor cocktail) for $30 \mathrm{~min}$ on ice. Lysates were centrifuged at $14,000 \mathrm{rpm}$ for $15 \mathrm{~min}$ at $4^{\circ} \mathrm{C}$, and protein concentrations were determined using Bradford assay (Bio-Rad). Western blot was performed according to standard procedures.

\section{Immunoprecipitation}

Cells were lysed in NP40 buffer (150 mM NaCl, 50 mM TrisHCL at $\mathrm{pH} 8,0,1 \% \mathrm{NP} 40,1 \%$ protease inhibitor cocktail) for 15 $\mathrm{min}$ on ice followed by three 5 -sec sonications. Protein lysates were spun down at $6000 \mathrm{rpm}$ for $5 \mathrm{~min}$, and protein concentrations were quantified by Bradford assay (Bio-Rad). Proteins were immunoprecipitated with $1 \mu \mathrm{g}$ of antibody per $1 \mathrm{mg}$ of protein and $10 \mu \mathrm{L}$ of Dynabeads Protein G (Invitrogen) overnight at $4^{\circ} \mathrm{C}$. The beads were washed four times for $15 \mathrm{~min}$ in $500 \mu \mathrm{L}$ of NP40 buffer and prepared for Western blotting.

\section{FACS analysis}

For AnnexinV-PI stainings, cells were treated or transfected with siRNA as described above and harvested at the indicated time points with trypsin. Next, the samples were incubated with incubation buffer (10 mM HEPES at pH 7.4, $140 \mathrm{mM} \mathrm{NaCL}, 2.5$ $\mathrm{mM} \mathrm{CaCl}_{2}$ ) supplemented with Annexin-V-FLUOS (Roche, catalog no. 11828681001$)$ and $0.1 \%$ propidium iodide solution (Sigma-Aldrich, catalog no. P4864) for $15 \mathrm{~min}$ at room temperature. The cells were then dissolved in incubation buffer and analyzed for active AnnexinV-PI staining by flow cytometry on a FACSCalibur (Becton Dickinson) using Cell Quest software.

For cell cycle analysis, cells were transfected with siRNA for $24 \mathrm{~h}$, irradiated with $3 \mathrm{~Gy}$, and harvested at the indicated time points with trypsin. The cells were washed in PBS and fixed with $4 \%$ PFA overnight at room temperature. PFA was removed by adding $95 \%$ ethanol for $1 \mathrm{~h}$ followed by rehydration in distilled water for $1 \mathrm{~h}$. The samples were then stained with DAPI solution and analyzed by flow cytometry on a FACSCalibur (Becton Dickinson) using Cell Quest software.

\section{HR and NHEJ assays}

Seventy-thousand U2OS (DR-GFP) and U2OS (EJ5-GFP) cells were seeded into six-well plates. Twenty-four hours later, cells were treated with the indicated siRNAs and, $8 \mathrm{~h}$ later, transfected with $1 \mu \mathrm{g}$ of an I-SceI vector using Lipofectamine 2000 (Invitrogen). The next day, the medium was changed; $24 \mathrm{~h}$ after this, cells were harvested by trypsination and washed with PBS, and the GFP signal arising from the recombination event was measured by flow cytometry on a FACSCalibur (as described above), with fluorescence detected in the FL1-H channel (logarithmic scale). The frequency of repair in cells transfected with the various siRNAs was calculated relative to cells transfected with control siRNA. Each data point represents the average \pm standard deviation from three independent experiments.

For cells overexpressing WRAP53 $\beta, 300,000$ cells were seeded into six-well plates. Twenty-four hours later, cells were transfected with an I-SceI vector together with a vector expressing Flag-empty or Flag-WRAP53 $\beta$ using Lipofectamine 2000 (Invitrogen). The next day, the medium was changed; $24 \mathrm{~h}$ after this, cells were harvested by trypsination and washed with PBS, and the GFP signal arising from the recombination event was measured by flow cytometry, as above. 


\section{Comet assay}

The alkaline comet assay was performed using the method described previously with some modifications (Sasaki et al. 1997). Briefly, cells were transfected with siRNA as described above for $24 \mathrm{~h}$ and irradiated. After $1 \mathrm{~h}$ or $4 \mathrm{~h}$, cells were harvested with trypsin and washed. Fifty-thousand cells were diluted in $125 \mu \mathrm{L}$ of PBS, of which $30 \mu \mathrm{L}$ was mixed with $70 \mu \mathrm{L}$ of low-melting-point agarose $(1 \%[\mathrm{w} / \mathrm{v}]$ in PBS) to a final concentration of $0.75 \%$. The resulting suspension was laid on the top of a previously prepared normal-melting-point agarose $(1 \%[\mathrm{w} / \mathrm{v}]$ in PBS) on frosted slides. The slides were then immersed in lysis buffer $(2.5 \mathrm{M} \mathrm{NaCl}, 100 \mathrm{mM}$ sodium EDTA, $10 \mathrm{mM}$ Tris- $\mathrm{HCl}$ at $\mathrm{pH} 10$ ) for $1 \mathrm{~h}$ at $4^{\circ} \mathrm{C}$ in the dark. After lysis, slides were placed in alkaline electrophoresis buffer $(0.3 \mathrm{M} \mathrm{NaOH}, 1 \mathrm{mM}$ sodiumEDTA) for $20 \mathrm{~min}$ at $4^{\circ} \mathrm{C}$ to denature DNA and express alkalilabile sites. Electrophoresis was carried out for $10 \mathrm{~min}$ at $4^{\circ} \mathrm{C}$ at $1.6 \mathrm{~V}$ per minute. The slides were then washed twice in neutralizing buffer $(0.4 \mathrm{M}$ Tris- $\mathrm{HCl}$ at $\mathrm{pH} 7.4)$ for $5 \mathrm{~min}$. DNA was stained with $20 \mu \mathrm{g} / \mathrm{mL}$ ethidium bromide per slide. More than 100 nuclei on each slide were examined for the presence of comet tails at $200 \times$ magnification. Comet images were analyzed using CometScore software (TriTek Corporation), and the tail moment was used as the primary measurement for the quantification of DNA damage. For the neutral comet assay, the cell suspension $(\sim 13,000$ cells in $30 \mu \mathrm{L}$ of $1 \times \mathrm{PBS})$ was mixed with 70 $\mu \mathrm{L}$ of $1 \%$ low-melting-point agarose type VII at a final concentration of $0.7 \%$. The suspensions were cast on microscope slides precoated with $1 \%$ regular agarose type IA and allowed to solidify for $30 \mathrm{~min}$ at $4^{\circ} \mathrm{C}$. After solidification, the slides were left for $2 \mathrm{~h}$ at $4^{\circ} \mathrm{C}$ in the dark in lysing buffer. The lysing buffer consisted of $2.5 \mathrm{M} \mathrm{NaCl}, 100 \mathrm{mM}$ EDTA, $10 \mathrm{mM}$ Tris-HCl, and $1 \% \mathrm{~N}$-lauroylsarcosine ( $\mathrm{pH} 9.5$ ). Immediately before use, $0.5 \%$ Triton X-100 and 10\% dimethylsulphoxide (DMSO) were added to the buffer and mixed for $20 \mathrm{~min}$. After lysis, the slides were washed three times ( $30 \mathrm{~min}$ each wash) with cold electrophoresis buffer $(1 \times \mathrm{TBE}$ at $\mathrm{pH} 8.3)$, left in a fresh portion of the buffer for $1 \mathrm{~h}$, and then placed in a horizontal gel electrophoresis unit filled with a fresh electrophoretic buffer. The slides were electrophoresed for $20 \mathrm{~min}$ at $8^{\circ} \mathrm{C}$ at $20 \mathrm{~V}(8 \mathrm{~mA})$. After electrophoresis, the slides were rinsed with $0.4 \mathrm{M}$ Tris $(\mathrm{pH} 7.5)$ three times for $5 \mathrm{~min}$, stained with $2.5 \mu \mathrm{g} / \mathrm{mL}$ ethidium bromide for $20 \mathrm{~min}$, and then washed three times ( 5 min each wash) with water and dried.

\section{Pulse-field gel electrophoresis}

Following siRNA treatment for $24 \mathrm{~h}$ and irradiation, $1 \times 10^{6}$ cells were resuspended in a solution containing $0.15 \mathrm{mM} \mathrm{NaCl}, 2 \mathrm{mM}$ $\mathrm{KH}_{2} \mathrm{PO}_{4}(\mathrm{pH} 6.8), 1 \mathrm{mM}$ EDTA, and $5 \mathrm{mM} \mathrm{MgCl}_{2}$. An equal volume of liquefied $1 \%$ low-melting-point agarose solution in the same buffer was added to this suspension while gently mixing. The mixture was then aliquoted into gel plug-casting forms. The resulting agarose blocks were transferred into a solution containing $10 \mathrm{mM} \mathrm{NaCl}, 10$ $\mathrm{mM}$ Tris- $\mathrm{HCl}$ (pH 9.5), 25 mM EDTA, 1\% lauroylsarcosine, and 200 $\mu \mathrm{g} / \mathrm{mL}$ proteinase $\mathrm{K}$ and incubated for $24 \mathrm{~h}$ at $50^{\circ} \mathrm{C}$ with continuous agitation. The plugs were rinsed three times for periods of $2 \mathrm{~h}$ at $4{ }^{\circ} \mathrm{C}$ in $10 \mathrm{mM}$ Tris-HCl (pH 8.0), and $1 \mathrm{mM}$ EDTA. Subsequently, the plugs were stored until use at $4^{\circ} \mathrm{C}$ in $50 \mathrm{mM}$ EDTA (pH 8.0). Plugs were then introduced into the $1 \%$ agarose gel, and PFGE was carried out using a horizontal gel chamber, a power supply, and a Switchback pulse controller (Hoefer Scientific Instruments). Electrophoresis was run at $12^{\circ} \mathrm{C}$ at $180 \mathrm{~V}$ in $0.5 \times \mathrm{TBE}(45 \mathrm{mM}$ Tris, $1.25 \mathrm{mM}$ EDTA, 45 $\mathrm{mM}$ boric acid at $\mathrm{pH} 8.0$ ), with the ramping rate changing from 0.8 to 30 sec over a 24-h period, applying a forward to reverse ratio of 3:1. DNA size calibration was performed using two sets of pulse markers with different size ranges, chromosomes from Saccharomyces cerevisiae $(225-2200 \mathrm{~kb})$, and a mixture of $\lambda$ DNA HindIII fragments, $\lambda$ DNA, and $\lambda$ DNA concatemers $(0.1-200 \mathrm{~kb})$ (Sigma). DNA was stained with ethidium bromide, visualized using a 305-nm UV light source, and photographed using Polaroid 665 positive/negative film.

\section{Acknowledgments}

We thank Dr. Jeremy Stark (Beckman Research Institute of the City of Hope) for the U2OS (EJ5-GFP) cell line, Dr. Nico Dantuma (Karolinska Institutet) for the GFP-RNF8 plasmid, Dr. Simon Bekker-Jensen for providing the Flag-RNF8 plasmid, Dr. Dan Durocher for the HA-RNF8 plasmid, Dr. Junjie Chen for providing the internally deleted Flag-RNF8 and HA-MDC1 deletion constructs, and Dr. Michael Huen for the RNF8 antibody. We thank Florian Salomons and Juan Castro (Karolinska Institutet) for technical assistance. This work was supported by grants from the Swedish Cancer Society (Cancerfonden), the Swedish Childhood Cancer Society (Barncancerfonden), the Swedish Research Foundation (VR), the Strategic Research Programme in Cancer (StratCan), the Royal Swedish Academy of Science, The Association for International Cancer Research (AICR), the Radiumhemmets Foundation, the Åke Wiberg Foundation, the Åke Olsson Foundation, the Magnus Bergvall Foundation, the Olle Engkvist Byggmästare Foundation, the National Institutes of Health (R01CA159826 and P30CA14236) (to M.B.K.), and the funds of the Karolinska Institutet.

\section{References}

Adamson B, Smogorzewska A, Sigoillot FD, King RW, Elledge SJ. 2012. A genome-wide homologous recombination screen identifies the RNA-binding protein RBMX as a component of the DNA-damage response. Nat Cell Biol 14: 318-328.

Coster G, Goldberg M. 2010. The cellular response to DNA damage: a focus on $\mathrm{MDC} 1$ and its interacting proteins. Nucleus 1: 166-178.

d'Adda di Fagagna F, Teo SH, Jackson SP. 2004. Functional links between telomeres and proteins of the DNA-damage response. Genes Dev 18: 1781-1799.

Doil C, Mailand N, Bekker-Jensen S, Menard P, Larsen DH, Pepperkok R, Ellenberg J, Panier S, Durocher D, Bartek J, et al. 2009. RNF168 binds and amplifies ubiquitin conjugates on damaged chromosomes to allow accumulation of repair proteins. Cell 136: 435-446.

Falck J, Coates J, Jackson SP. 2005. Conserved modes of recruitment of ATM, ATR and DNA-PKcs to sites of DNA damage. Nature 434: 605-611.

Farnebo M. 2009. Wrap53, a novel regulator of p53. Cell Cycle 15: 2343-2346.

Garcia-Closas M, Kristensen V, Langerod A, Qi Y, Yeager M, Burdett L, Welch R, Lissowska J, Peplonska B, Brinton L, et al. 2007. Common genetic variation in TP53 and its flanking genes, WDR79 and ATP1B2, and susceptibility to breast cancer. Int J Cancer 121: 2532-2538.

Garvin S, Tiefenböck K, Farnebo L, Thunell LK, Farnebo M and Roberg M. 2014. Nuclear expression of WRAP53 $\beta$ is associated with a positive response to radiotherapy and improved overall survival in patients with head and neck squamous cell carcinoma. Oral Oncol doi: 10.1016/j.oraloncology.2014.10.003.

Goldstein M, Derheimer FA, Tait-Mulder J, Kastan MB. 2013. Nucleolin mediates nucleosome disruption critical for DNA double-strand break repair. Proc Natl Acad Sci 110: 1687416879.

Gunn A, Stark JM. 2012. I-SceI-based assays to examine distinct repair outcomes of mammalian chromosomal double strand breaks. Methods Mol Biol 920: 379-391.

Huen MS, Grant R, Manke I, Minn K, Yu X, Yaffe MB, Chen J. 2007. RNF8 transduces the DNA-damage signal via histone 
ubiquitylation and checkpoint protein assembly. Cell 131: 901-914.

Jackson SP, Bartek J. 2009. The DNA-damage response in human biology and disease. Nature 461: 1071-1078.

Kolas NK, Chapman JR, Nakada S, Ylanko J, Chahwan R, Sweeney FD, Panier S, Mendez M, Wildenhain J, Thomson TM, et al. 2007. Orchestration of the DNA-damage response by the RNF8 ubiquitin ligase. Science 318: 1637-1640.

Lan Q, Zhang L, Shen M, Jo WJ, Vermeulen R, Li G, Vulpe C, Lim S, Ren X, Rappaport SM, et al. 2009. Large-scale evaluation of candidate genes identifies associations between DNA repair and genomic maintenance and development of benzene hematotoxicity. Carcinogenesis 30: 50-58.

Luijsterburg MS, Acs K, Ackermann L, Wiegant WW, BekkerJensen S, Larsen DH, Khanna KK, van Attikum H, Mailand N, Dantuma NP. 2012. A new non-catalytic role for ubiquitin ligase RNF8 in unfolding higher-order chromatin structure. EMBO J 31: 2511-2527.

Mahmoudi S, Henriksson S, Corcoran M, Mendez-Vidal C, Wiman KG, Farnebo M. 2009. Wrap53, a natural p53 antisense transcript required for p53 induction upon DNA damage. Mol Cell 33: 462-471.

Mahmoudi S, Henriksson S, Weibrecht I, Smith S, Soderberg O, Stromblad S, Wiman KG, Farnebo M. 2010. WRAP53 is essential for Cajal body formation and for targeting the survival of motor neuron complex to Cajal bodies. PLOS Biol 8: e1000521.

Mahmoudi S, Henriksson S, Farnebo L, Roberg K, Farnebo M. 2011. WRAP53 promotes cancer cell survival and is a potential target for cancer therapy. Cell Death Dis 2: e114.

Mailand N, Bekker-Jensen S, Faustrup H, Melander F, Bartek J, Lukas C, Lukas J. 2007. RNF8 ubiquitylates histones at DNA double-strand breaks and promotes assembly of repair proteins. Cell 131: 887-900.

Marteijn JA, Bekker-Jensen S, Mailand N, Lans H, Schwertman P, Gourdin AM, Dantuma NP, Lukas J, Vermeulen W. 2009. Nucleotide excision repair-induced H2A ubiquitination is dependent on MDC1 and RNF8 and reveals a universal DNA damage response. J Cell Biol 186: 835-847.

Matsuoka S, Ballif BA, Smogorzewska A, McDonald ER 3rd, Hurov KE, Luo J, Bakalarski CE, Zhao Z, Solimini N, Lerenthal Y, et al. 2007. ATM and ATR substrate analysis reveals extensive protein networks responsive to DNA damage. Science 316: 1160-1166.

Medrek K, Magnowski P, Masojc B, Chudecka-Glaz A, Torbe B, Menkiszak J, Spaczynski M, Gronwald J, Lubinski J, Gorski B. 2013. Association of common WRAP 53 variant with ovarian cancer risk in the Polish population. Mol Biol Rep 40: $2145-2147$.

Meerang M, Ritz D, Paliwal S, Garajova Z, Bosshard M, Mailand N, Janscak P, Hubscher U, Meyer H, Ramadan K. 2011. The ubiquitin-selective segregase $\mathrm{VCP} / \mathrm{p} 97$ orchestrates the response to DNA double-strand breaks. Nat Cell Biol 13: 1376 1382.

Orthwein A, Fradet-Turcotte A, Noordermeer SM, Canny MD, Brun CM, Strecker I, Escribano-Diaz C, Durocher D. 2014. Mitosis inhibits DNA double-strand break repair to guard against telomere fusions. Science 344: 189-193.

Paulsen RD, Soni DV, Wollman R, Hahn AT, Yee MC, Guan A, Hesley JA, Miller SC, Cromwell EF, Solow-Cordero DE, et al. 2009. A genome-wide siRNA screen reveals diverse cellular processes and pathways that mediate genome stability. Mol Cell 35: 228-239.

Petermann E, Helleday T. 2010. Pathways of mammalian replication fork restart. Nat Rev Mol Cell Biol 11: 683687.
Pierce AJ, Johnson RD, Thompson LH, Jasin M. 1999. XRCC3 promotes homology-directed repair of DNA damage in mammalian cells. Genes Dev 13: 2633-2638.

Saleh-Gohari N, Bryant HE, Schultz N, Parker KM, Cassel TN, Helleday T. 2005. Spontaneous homologous recombination is induced by collapsed replication forks that are caused by endogenous DNA single-strand breaks. Mol Cell Biol 25: 7158-7169.

Sasaki YF, Saga A, Akasaka M, Yoshida K, Nishidate E, Su YQ, Matsusaka N, Tsuda S. 1997. In vivo genotoxicity of orthophenylphenol, biphenyl, and thiabendazole detected in multiple mouse organs by the alkaline single cell gel electrophoresis assay. Mutat Res 395: 189-198.

Schildkraut JM, Goode EL, Clyde MA, Iversen ES, Moorman PG, Berchuck A, Marks JR, Lissowska J, Brinton L, Peplonska B, et al. 2009. Single nucleotide polymorphisms in the TP53 region and susceptibility to invasive epithelial ovarian cancer. Cancer Res 69: 2349-2357.

Stewart GS, Wang B, Bignell CR, Taylor AM, Elledge SJ. 2003. MDC1 is a mediator of the mammalian DNA damage checkpoint. Nature 421: 961-966.

Stiff T, O'Driscoll M, Rief N, Iwabuchi K, Lobrich M, Jeggo PA. 2004. ATM and DNA-PK function redundantly to phosphorylate $\mathrm{H} 2 \mathrm{AX}$ after exposure to ionizing radiation. Cancer Res 64: 2390-2396.

Stirnimann CU, Petsalaki E, Russell RB, Muller CW. 2010. WD40 proteins propel cellular networks. Trends Biochem Sci 35: 565-574.

Stucki M, Clapperton JA, Mohammad D, Yaffe MB, Smerdon SJ, Jackson SP. 2005. MDC1 directly binds phosphorylated histone $\mathrm{H} 2 \mathrm{AX}$ to regulate cellular responses to DNA double-strand breaks. Cell 123: 1213-1226.

Sy SM, Huen MS, Chen J. 2009. PALB2 is an integral component of the BRCA complex required for homologous recombination repair. Proc Natl Acad Sci 106: 7155-7160.

Tycowski KT, Shu MD, Kukoyi A, Steitz JA. 2009. A conserved WD40 protein binds the Cajal body localization signal of scaRNP particles. Mol Cell 34: 47-57.

Velma V, Carrero ZI, Cosman AM, Hebert MD. 2010. Coilin interacts with $\mathrm{Ku}$ proteins and inhibits in vitro non-homologous DNA end joining. FEBS Lett 584: 4735-4739.

Venkitaraman AR. 2002. Cancer susceptibility and the functions of BRCA1 and BRCA2. Cell 108: 171-182.

Venteicher AS, Abreu EB, Meng Z, McCann KE, Terns RM, Veenstra TD, Terns MP, Artandi SE. 2009. A human telomerase holoenzyme protein required for Cajal body localization and telomere synthesis. Science 323: 644-648.

Wang J, Gong Z, Chen J. 2011. MDC1 collaborates with TopBP1 in DNA replication checkpoint control. J Cell Biol 193: 267273.

Xia B, Sheng Q, Nakanishi K, Ohashi A, Wu J, Christ N, Liu X, Jasin M, Couch FJ, Livingston DM. 2006. Control of BRCA2 cellular and clinical functions by a nuclear partner, PALB2. Mol Cell 22: 719-729.

Xu C, Min J. 2011. Structure and function of WD40 domain proteins. Protein Cell 2: 202-214.

Zhang J, Ma Z, Treszezamsky A, Powell SN. 2005. MDC1 interacts with Rad51 and facilitates homologous recombination. Nat Struct Mol Biol 12: 902-909.

Zhang F, Ma J, Wu J, Ye L, Cai H, Xia B, Yu X. 2009. PALB2 links BRCA1 and BRCA2 in the DNA-damage response. Curr Biol 19: 524-529.

Zhong F, Savage SA, Shkreli M, Giri N, Jessop L, Myers T, Chen R, Alter BP, Artandi SE. 2011. Disruption of telomerase trafficking by TCAB1 mutation causes dyskeratosis congenita. Genes Dev 25: 11-16. 


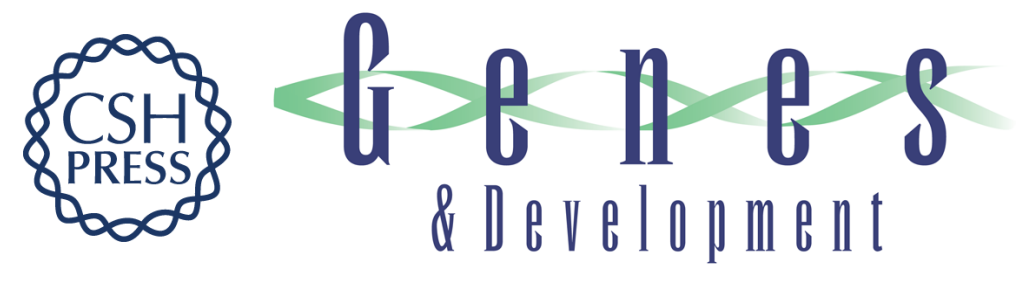

\section{The scaffold protein WRAP53 $\beta$ orchestrates the ubiquitin response critical for DNA double-strand break repair}

Sofia Henriksson, Hanif Rassoolzadeh, Elisabeth Hedström, et al.

Genes Dev. 2014, 28:

Access the most recent version at doi:10.1101/gad.246546.114

Supplemental
Material

References This article cites 45 articles, 15 of which can be accessed free at: http://genesdev.cshlp.org/content/28/24/2726.full.html\#ref-list-1

Creative This article, published in Genes \& Development, is available under a Creative Commons Commons License (Attribution 4.0 International), as described at License http://creativecommons.org/licenses/by/4.0.

Email Alerting Receive free email alerts when new articles cite this article - sign up in the box at the top Service right corner of the article or click here.

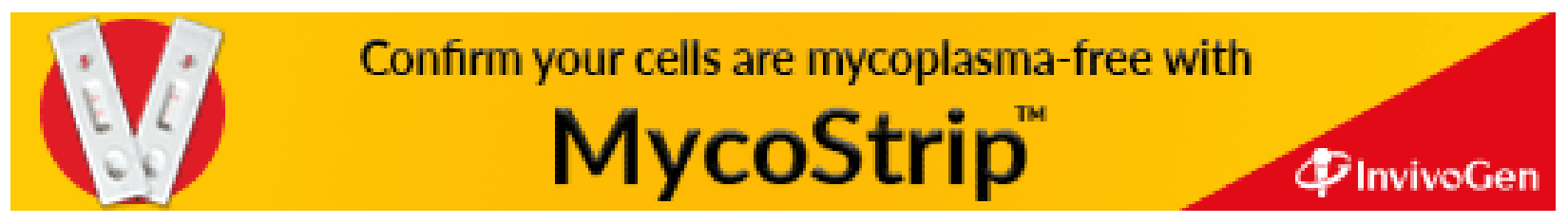

